\title{
Review \\ Evolution and Application of Genome Editing Techniques for
Achieving Food and Nutritional Security
}

\author{
Sajid Fiaz ${ }^{1, *(\mathbb{D})}$, Sunny Ahmar ${ }^{2}$, Sajjad Saeed ${ }^{3}$, Aamir Riaz ${ }^{4}$, Freddy Mora-Poblete ${ }^{2}\left(\mathbb{D}\right.$ and Ki-Hung Jung ${ }^{5, *(\mathbb{D}}$ \\ 1 Department of Plant Breeding and Genetics, The University of Haripur, Haripur 22620, Pakistan \\ 2 Institute of Biological Sciences, University of Talca, 2 Norte 685, Talca 3460000, Chile; \\ Sunnyahmar13@gmail.com (S.A.); morapoblete@gmail.com (F.M.-P.) \\ 3 Department of Forestry and Wildlife Management, University of Haripur, Haripur 22620, Pakistan; \\ sajjad.saeed@uoh.edu.pk \\ 4 State Key Laboratory of Rice Biology, China National Rice Research Institute, Hangzhou 310006, China; \\ aamirriaz33@gmail.com \\ 5 Graduate School of Biotechnology \& Crop Biotech Institute, Kyung Hee University, Yongin 17104, Korea \\ * Correspondence: sfiaz@uoh.edu.pk (S.F.); khjung2010@khu.ac.kr (K.-H.J.)
}

Citation: Fiaz, S.; Ahmar, S.;

Saeed, S.; Riaz, A.; Mora-Poblete, F.; Jung, K.-H. Evolution and

Application of Genome Editing Techniques for Achieving Food and Nutritional Security. Int. J. Mol. Sci. 2021, 22, 5585. https://doi.org/ $10.3390 /$ ijms 22115585

Academic Editor: Hikmet Budak

Received: 12 April 2021

Accepted: 20 May 2021

Published: 25 May 2021

Publisher's Note: MDPI stays neutral with regard to jurisdictional claims in published maps and institutional affiliations.

Copyright: (c) 2021 by the authors. Licensee MDPI, Basel, Switzerland. This article is an open access article distributed under the terms and conditions of the Creative Commons Attribution (CC BY) license (https:// creativecommons.org/licenses/by/ $4.0 /)$.

\begin{abstract}
A world with zero hunger is possible only through a sustainable increase in food production and distribution and the elimination of poverty. Scientific, logistical, and humanitarian approaches must be employed simultaneously to ensure food security, starting with farmers and breeders and extending to policy makers and governments. The current agricultural production system is facing the challenge of sustainably increasing grain quality and yield and enhancing resistance to biotic and abiotic stress under the intensifying pressure of climate change. Under present circumstances, conventional breeding techniques are not sufficient. Innovation in plant breeding is critical in managing agricultural challenges and achieving sustainable crop production. Novel plant breeding techniques, involving a series of developments from genome editing techniques to speed breeding and the integration of omics technology, offer relevant, versatile, cost-effective, and less time-consuming ways of achieving precision in plant breeding. Opportunities to edit agriculturally significant genes now exist as a result of new genome editing techniques. These range from random (physical and chemical mutagens) to non-random meganucleases (MegaN), zinc finger nucleases (ZFNs), transcription activator-like effector nucleases (TALENs), clustered regularly interspaced short palindromic repeats (CRISPR)/associated protein system 9 (CRISPR/Cas9), the CRISPR system from Prevotella and Francisella1 (Cpf1), base editing (BE), and prime editing (PE). Genome editing techniques that promote crop improvement through hybrid seed production, induced apomixis, and resistance to biotic and abiotic stress are prioritized when selecting for genetic gain in a restricted timeframe. The novel CRISPR-associated protein system 9 variants, namely BE and PE, can generate transgene-free plants with more frequency and are therefore being used for knocking out of genes of interest. We provide a comprehensive review of the evolution of genome editing technologies, especially the application of the third-generation genome editing technologies to achieve various plant breeding objectives within the regulatory regimes adopted by various countries. Future development and the optimization of forward and reverse genetics to achieve food security are evaluated.
\end{abstract}

Keywords: genome editing; mutation; hybrid seed production; quality improvement; regulatory concerns; genetic gain; speed breeding

\section{Introduction}

It is estimated that approximately 800 million people around the globe are facing acute food shortages, and around 2 billion are facing nutrient deficiency [1]. Food and nutritional insecurity results in physical and mental impairment, reduced resistance to infectious diseases, and premature infant deaths [2]. This is complicated by the fact that the global human population is predicted to exceed 8.3 billion people by 2030 [3]. 
There is a need to significantly boost agricultural production by approximately $50 \%$ from current levels to ensure the availability of food [4]. To overcome these challenges and achieve the second of the United Nation's Sustainable Development Goals, namely that of "zero hunger and improved nutrition," intensive efforts are required to shift from traditional agricultural production systems to modern agricultural ones [5]. Plants are a basic source of food and energy, sustaining life on earth. A movement known as the green revolution began in the mid-20th century, where the use of agrochemicals and adoption of best agronomic practices contributed to optimized crop production along with traditional breeding techniques to develop semi-dwarf crop varieties with superior yield advantages [6]. However, the continuous application of agrochemicals has had serious negative environmental consequences. Future technologies must focus on mitigating these impacts and developing agricultural systems that are more resilient to climate stress. Improvements in sustainable crop production are essential to facilitate socio-economic development. Researchers have employed natural and induced mutations, heterosis breeding, and genetic manipulation techniques to promote sustainable crop production and enhance nutritional and food security [7]. Plant breeding and other technologies have made significant contributions toward minimizing hunger and extreme poverty over the last decades [8]. However, researchers have concluded that traditional breeding efforts alone cannot meet the ever-increasing demand for food for the human population [9]. Therefore, agricultural experts agree there is a need to convert to modern plant breeding approaches, especially novel plant breeding techniques (NPBTs) that are more flexible, reliable, and sustainable, to increase production in a way that does not impact negatively on natural resources [10].

The novel developments in agricultural biotechnology include engineering metabolic pathways that control traits of interest [11,12]. These have helped to develop crop plants with better agronomic benefits, nutrition, and resistance to both biotic and abiotic threats. These technologies complement the shortcomings of traditional breeding methods and are flexible, allowing for the use of genomic data of several models and non-model plant species. NPBTs depend largely on the public genome sequence database to target attributes of interest [13]. Traditional plant breeding tools and classical genome editing techniques (GETs) are unable to meet the demands of high precision, efficiency, and time constraints, guiding researchers to adopt NPBTs. The NPBTs include CRISPR/Cas9, CRISPR/Cpf1, BE, and PE. These techniques have proved to be powerful tools for the successful modification of genome sequences in a simple and precise manner [14]. GETs have been applied to several crop plants, and desirable phenotypes have been successfully obtained. NPBTs have enabled the production of transgene-free plants that are categorized as non-genetically modified (GM) crops. The NPBTs available can be exploited for various crop improvement programs to ensure nutritional and food security for increasing human population levels [15].

We have summarized the major developments in GETs in recent years, with a specific focus on the use of third-generation GETs for crop improvement programs. The discussion emphasizes yield and grain quality, hybrid seed production, and epigenetic modifications for the regulation of important traits in crops essential for food and nutritional security. Moreover, this review will enhance the understanding of speed breeding, omics, and precision breeding to achieve zero hunger, especially in developing countries. The discussion on the regulatory concerns of several countries regarding genome editing for crops and their derived products will also help to broaden the perspective of the scientific community; moreover, the integration of omics, speed breeding, and genome editing will foster our understanding to achieve genetic gain essential to meet global food demands.

\section{Evolution of GETs}

Traditional and modern crop improvement programs employing naturally existing or induced genetic variations require labor-intensive, time-consuming, and costly characterization of progenies for a series of generations derived from genetic crosses [16]. Researchers 
are developing new techniques to overcome the constraints of previous agricultural methods to meet the increasing demand for food [17]. NPBTs cover a broad range of techniques and are broadly categorized into three generations, although developments are still taking place to make GETs more user-friendly and efficient. Developments in NPBTs have contributed significantly to crop improvement programs compared to classical breeding efforts. NPBTs have the potential to modify endogenous genes to generate favorable phenotypes, similar to crop plants developed through traditional breeding [18]. The potential of NPBTs to enhance production has been documented in various crop species. A detailed comparison of the three generations of GETs is provided in Table 1, whereas Figure 1 depicts the timeline for the different developmental stages of GETs. This information can assist in decision-making about employing GETs in relation to specific objectives in crop breeding programs, especially the third generation. There are currently four families of engineered nuclease being used in genome editing, namely the engineered MegaN, ZFNs, TALENs, and the CRISPR/Cas9 nuclease systems $[19,20]$. With their potential applications for food security, we only discuss third-generation GETs in this review.

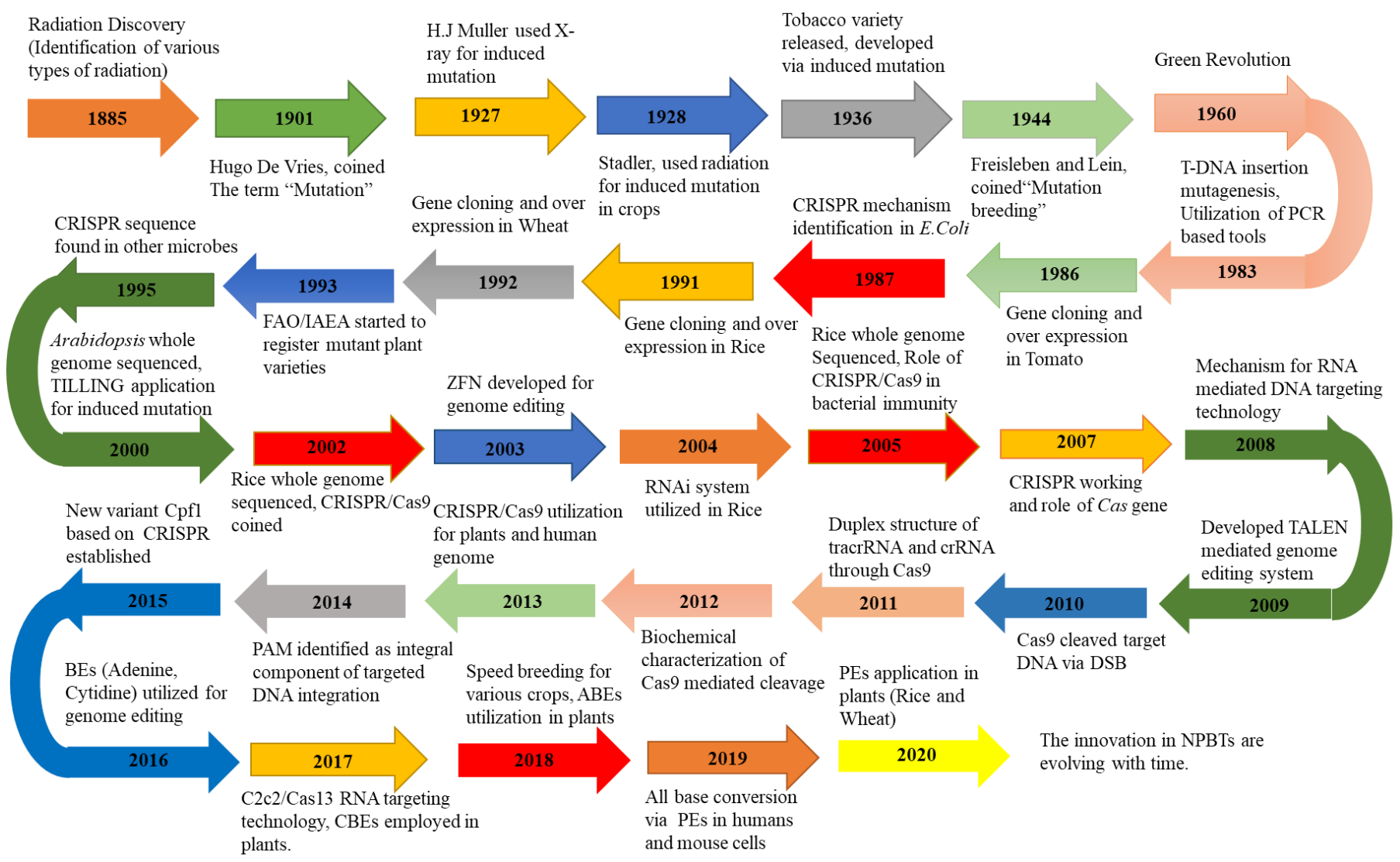

Figure 1. A brief history of different versions of GETs, showing historical events. CRISPR = clustered regularly interspaced short palindromic repeats; Cas9 = CRISPR-associated protein system 9; Cpf1 = CRISPR system from Prevotella and Francisella1; BEs = base editors; PEs = prime editors; T-DNA = transgenic deoxyribonucleic acid; PCR = polymerase chain reaction; FAO = food and agriculture organization; IAEA = international atomic energy agency; DSB = double-stranded breaks; $\mathrm{RNAi}=\mathrm{RNA}$ interference; tracrRNA = trans-activating CRISPR RNA; PAM = protospacer adjacent motif; NPBTs = novel plant breeding techniques. 
Table 1. Comparison of MegaN, ZFN, TALEN, CRISPR/Cas9, Cpf1, base editing, and prime editing.

\begin{tabular}{|c|c|c|c|c|c|c|c|}
\hline Property & MegaN & ZFN & TALEN & CRISPR/Cas9 & CRISPR/Cpf1 & $\mathrm{BE}$ & PE \\
\hline $\begin{array}{l}\text { DNA binding } \\
\text { determinant }\end{array}$ & Meganuclease & Zinc finger protein & $\begin{array}{l}\text { Transcription- } \\
\text { activator-like } \\
\text { effector }\end{array}$ & CrRNA/sgRNA & CrRNA/Cpf1 & $\mathrm{dCas} / \mathrm{nCas}$ & nCas9/pegRNA \\
\hline Recognition & Protein-DNA & Protein-DNA & Protein-DNA & RNA-DNA & RNA-DNA-Protein & RNA-DNA-Protein & RNA-DNA-Protein \\
\hline Endonuclease & Meganuclease & FokI & FokI & Cas9 & Cpf1 & $d$ Cas & pegRNA \\
\hline Mutation rate & High & Medium & Medium & Low & High & High & Very High \\
\hline Off-target effects & High & High & Low & Variable & Low & Low & Very low \\
\hline Mechanism of action & \multicolumn{6}{|c|}{$\begin{array}{c}\text { Able to induce double-strand breaks (DSB) with two possibilities of Non-homology end joining (NHEJ) and homology-directed repair (HDR), } \\
\text { depends on the designing tool }\end{array}$} & No DSBs \\
\hline Design feasibility & $\begin{array}{c}\text { Difficult, may require } \\
\text { substantial efforts to } \\
\text { design } \\
\text { engineered protein }\end{array}$ & $\begin{array}{c}\text { Required customized } \\
\text { protein for each gene } \\
\text { sequence. } \\
\text { Oligomerized pool } \\
\text { engineering (OPEN) } \\
\text { used to select for new } \\
\text { zinc finger assays }\end{array}$ & $\begin{array}{l}\text { Technical challenging } \\
\text { due to repeating } \\
\text { sequence. Golden gate } \\
\text { molecular cloning } \\
\text { used to produce a } \\
\text { TALE array }\end{array}$ & $\begin{array}{l}\text { Easy to clone, only } \\
\text { 20nt to targeting each } \\
\text { gene expressed in } \\
\text { a plasmid. }\end{array}$ & Easy & Easy & Easy \\
\hline Multiplexing & Not possible & Difficult & Difficult & Easier & Easier & Easier & Not tested yet \\
\hline $\begin{array}{l}\text { Methylation } \\
\text { sensitivity }\end{array}$ & High & High & High & Low & & & \\
\hline $\begin{array}{l}\text { Target recognition } \\
\text { efficiency }\end{array}$ & Low & High & High & High & High & Very high & Very high \\
\hline Cost-effectiveness & No & No & Moderate & High & High & Very high & Very high \\
\hline Application & $\begin{array}{l}\text { Human, Animals, } \\
\text { and Plants }\end{array}$ & $\begin{array}{l}\text { Human, Animals, } \\
\text { and Plants }\end{array}$ & $\begin{array}{l}\text { Human, Animals, } \\
\text { and Plants }\end{array}$ & $\begin{array}{c}\text { Human, Animals, } \\
\text { and Plants }\end{array}$ & $\begin{array}{c}\text { Human, Animals, } \\
\text { and Plants }\end{array}$ & $\begin{array}{c}\text { Human, Animals, } \\
\text { and Plants }\end{array}$ & $\begin{array}{c}\text { Human, Plants (rice } \\
\text { and wheat) }\end{array}$ \\
\hline References & [21] & {$[22,23]$} & {$[22,23]$} & {$[22,23]$} & [24] & [25-27] & [28] \\
\hline
\end{tabular}

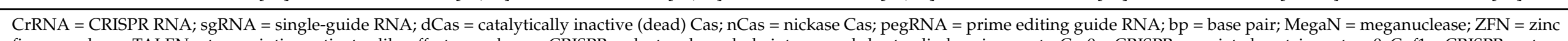

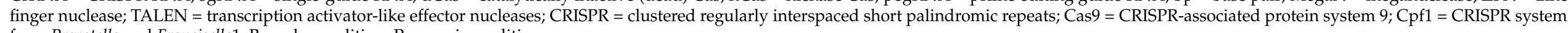
from Prevotella and Francisella1; Bes = base editing; Pes = prime editing. 


\subsection{Third-Generation GETs}

\subsubsection{CRISPR/Cas9 System}

The CRISPR/Cas9, and related versions, are the most advanced third-generation GETs in plant biology [29]. The Cas9 system requires a short guide sequence (sgRNA) to direct Cas9 nuclease to cleave the target site [30]. Cas9 has the ability to cleave the doublestranded DNA target site complementary to sgRNA and successfully deploy various living backgrounds such as bacteria [31], eukaryotic cells (Cong et al., 2013), animal cells, mammalian systems [32,33], and plants [34].

\subsubsection{CRISPR/Cpf1 System}

The development of a toolkit for genome editing through the addition of the class 2 CRISPR effector, Cpf1, has strengthened agricultural research [35]. The system from Prevotella and Francisella1 is known as Cpf1 but was previously known as Cas12a. This Cpf1 showed accuracy and efficiency in the genetic modification system, gaining researcher confidence [36]. The endonuclease of Cpf1 is comparatively smaller than Cas9 and therefore requires shorter CRISPR RNA (crRNA) with higher working efficiency [37]. The single RNA helps to bind Cpf1 upstream of the protospacer adjacent motif (PAM) and cuts DNA at a distance from the seed region, introducing five base pairs (bp) at the proximal end [35]. The Cpf1 system bypasses the trans-activating crRNA (tracrRNA) requirement for the maturation of crRNAs [38]. The Cpf1 system also efficiently manipulates the target site through T-rich PAM, whereas Cas9 technology requires a G-rich PAM sequence. It modifies the targeted region by keeping PAM sequencing intact based on its origin orthology [39]. The target-activated non-specific ssDNase activity, catalyzed by the same active site responsible for site-specific double-stranded DNA (dsDNA) cutting, is a fundamental property of CRISPR/Cpf1 enzymes. Moreover, the active nuclease site of Cpf1 cuts target single-strand DNA (ssDNA) in cis and the non-target ssDNA in transposition. This nuclease can only embed one DNA strand at a time, so the target and non-target DNA strands are presumably cleaved sequentially. This sequential cleavage of DNA elucidates the mechanism of staggered-end DNA break induced by Cpf1 [40]. There are several online tools, specifically the Cpf1-database (http:/ / www.rgenome.net/cpf1-database/, accessed on 10 January 2021), which help to find the potential target site and design the gRNA in a fast yet easy way.

\subsubsection{BE System}

A novel approach known as BE achieves more efficient genome manipulation with irreversibly based conversion at the target site. This technique is much simpler and more precise in nature, allowing the conversion of nucleotides without the formation of doublestranded breaks (DSBs) in the target DNA [41]. The change of cytosine (C) to thymine (T), called cytosine BE (CBE), demonstrated high efficiency [25,42]. The CBE system consists of four elements: (i) single sgRNA, (ii) dCas9, (iii) $\mathrm{C}$ deaminase, and (iv) uracil DNA glycosylase inhibitor (UGI). With an in-depth molecular understanding of deaminases, another system called adenine $\mathrm{BE}(\mathrm{ABE})$ was developed with the conversion efficiency of adenine (A) to guanine $(\mathrm{G})[43,44]$. The BEs restrict indel formation at both target and off-target sites without requiring DSBs for DNA modification [45]. This further allows single bp conversion; that is, bp substitutions without depending on donor DNA [41]. Recently, several BEs other than CBE and ABE have been developed, for example, rBEs (conversion from $\mathrm{C}$ to $\mathrm{U}$ ). Moreover, another addition to GETs has taken place with the addition of a new technique called PE.

\subsubsection{PE System}

The PE system allows manipulation of all 12 base-to-base conversions (transition and transversion), bypassing DSBs in targeted DNA [28]. The following technique utilizes Cas9 nickase bind with reverse transcriptase and PE guide RNA (peg RNA), consisting of a primer binding site (PBS), a target sequence, and a sequence to identify the target site. 
Hybridization of target DNA-pegRNA PBS and target DNA-reverse transcripts resulted in minimum off-target effects. To date, three generations of PE have been developed and categorized on the basis of their editing efficiency. First-generation PE (PE1) utilizes the mouse-murine leukemia virus (M-MLV RT), an RNA-dependent DNA polymerase, linked to the C-terminus of Cas9 nickase (H840A), which is an endonuclease with one inactivated domain. The efficiency of PE1 reached values of $0.7 \%$ to $5.5 \%$ when point transversions were introduced. The efficiency depended on the PBS length, and for different genes, various lengths of PBS (from eight to 16 nucleotides) resulted in higher efficiencies [46]. The efficiency of a second-generation PE (PE2) was enhanced, exhibiting a 1.6- to 5.1-fold improvement in the efficiency of introducing point mutations when compared to PE1. Furthermore, editing efficiency can be increased [28]. All 12 possible transition and transversion mutations were generated with $33 \%( \pm 7.9 \%)$ efficiency in the PE3 system. The PE system has hampered the modification of promoter/introns more easily, allowing an allelic replacement at the target site to be feasible. It is noteworthy that the mutation efficiency of PE is similar to that of the BE system; however, the specificity was much higher than that of previously discussed GETs. The PE system is at the foundation stage, and further developments and applications for crop improvement programs will take place over time.

\section{Application of GETs in Agriculture to Ensure Food Security}

3.1. GETs for Crop Improvements

The challenge of food and nutritional security poses serious threats to human life and health, especially in developing countries. Over recent years, biotic (such as bacteria, insects, fungi, and viruses), abiotic (such as limited water supply, edaphic factors, heavy metal toxicity), and climatic (such as low and high temperatures, flooding, rainfall shifts) stresses have impacted negatively on crop production [47]. Based on the prevailing circumstances, researchers agree that traditional plant breeding methods alone cannot achieve a sustainable caloric supply to the expanding human population. Consequently, there is a need to switch to alternative cost-effective technologies with more flexibility and reliability to boost agricultural productivity with little or no pressure on non-renewable natural resources [10]. Current breeding methods focus on the increase in yield and yield-related traits per unit area to increase agricultural production. Thus, breeders play a key role in promoting agronomic traits to achieve economic gains [9]. Innovations in GETs have assisted in developing germplasms with improved characteristics and more accuracy over recent years.

\subsubsection{The CRISPR/Cas9 System-Proof of Concept for Crop Improvement}

Improved traits in agriculturally important crops resulting from GETs, especially for yield and related traits, resistance to biotic and abiotic factors, and enhanced environmental resilience, are assisting in developing food security. The knockout of negative regulating loci, e.g., GS3, DEP1, GS5, GW2, Gnla, and TGW6, which control grain yield in O. sativa L., resulted in a significantly improved grain yield in mutant plants [48]. Multiplex knockout of genes GW2, GW5, and TGW6 resulted in a significant increase in the thousand-grain weight of rice grains [49]. Genetic manipulation of OsERF922 resulted in the reduction in rice blast disease through pathogen infection [50]. Similarly, genome editing of the negative regulator gene, Bsrk-1, significantly reduced blast resistance without compromising yield [51]. The use of agrochemicals for crop production may cause serious environmental and human health-related impacts. Therefore, researchers are investigating herbicide resistance in crop plants [52]. The targeted manipulation of the ALS1 gene controlling herbicide tolerance in rice had positive results [51], and the outcome of the investigation showed that the homology-directed repair (HDR) system was successful. Similarly, targeted mutagenesis in the second coding region of BEL in the Japonica rice cultivar, Nipponbare, showed resistance to the herbicides bentazon and sulfonylurea [53]. The seedling stage of rice is more prone to low-temperature stress, and the targeted modification of the transcription factor TIFY1b 
and gene OsAnn3 significantly improved resistance to cold stress in mutant rice. To reduce heavy metal accumulation, Tang et al. [54] knocked out the OsNramp5 transporter gene for cadmium $(\mathrm{Cd})$, and the resultant mutant rice displayed a low accumulation of $\mathrm{Cd}$ in roots, shoots, and seeds.

Wheat (T. aestivum L.) provides caloric requirements to much of the human population worldwide. For disease resistance in wheat, the mildew-resistance locus $O$ (TaMLO) gene was knocked out using the CRISPR/Cas9 system [55]. The mutant plants displayed resistance to powdery mildew disease caused by Blumeria graminis f. sp. Tritici (btg) s. Moreover, Gil-Humanes et al. [56] employed geminiviral-dependent DNA replicons in the wheat dwarf virus (WDV) to express Cas9 cassettes, which demonstrated a 12-fold increase in the expression of endogenous ubiquitin genes. This methodology and the promising nature of the results create opportunities for engineering complex genomes. Genetic manipulation of the wheat dehydration-responsive element-binding protein 2 (TaDREB2) and the wheat ethylene-responsive factor 3 (TaERF3) genes through protoplasts resulted in a 70\% success rate for an improved response of mutant plants to abiotic stresses [57]. An efficient method for biolistic delivery in the host genome has been introduced to overcome the issue of transgene integration and off-target effects. This method allows for the delivery of ribonucleoproteins (RNP) in the targeted genome that degrades rapidly, allowing reduction in off-target effects. Liang et al. [58] used the same procedure for TaGW2 and TaGASR7 in two wheat varieties and recorded reduced off-target mutations in mutant plants. Transgene-free editing will help to circumvent strict regulatory measures and mitigate lengthy breeding procedures, for example, backcrossing to obtain transgene-free plants.

$Z$. mays is one of the leading cereal crops, and phytic acid constitutes approximately $70 \%$ of maize seeds. Liang et al. [59] knocked out ZmIPK1A, ZmIPK, and ZmMRP4 to control phytic acid synthesis. The AUXIN REGULATED GENE INVOLVED IN ORGAN SIZE (ARGOS) gene family is a negative regulator of the ethylene response and signal transduction. The overexpression of the ARGOS gene displayed drought stress tolerance in mutant plants and the identification of novel allelic variants that can be further used in future maize breeding programs. The novel allelic variants of the ARGOS 8 gene, that is, ARGOS8-v1 and ARGOS8-v2, were manipulated using CRISPR/Cas9. The resulting mutants were evaluated in multi-location trials. Mutants displayed a promising response compared to the wild-type under stress conditions [60]. Similarly, the phytoene synthase (PSY1) gene was manipulated using the U6 snRNA promoter, and the psy1 mutant displayed white kernels and albino seedlings with no off-target mutations. Based on these findings, it can be assumed that the CRISPR/Cas9 system has been successfully employed for targeted mutagenesis of cereals. It is predicted that new developments in GETs can help overcome the limitations faced during genetic manipulation.

\subsubsection{The CRISPR/Cpf1 System-a Proof of Concept for Crop Improvement}

The CRISPR/Cpf1 system has been employed for targeted mutagenesis of Arabidopsis, O. sativa, Nicotiana tabacum, Glycine max, Z. mays, Citrus X sinensis, and Gossypium hirsutum, etc. [61-66]. The CRISPR/Cpf1- and CRISPR/Cas9-mediated editing has been used for genome editing of the epidermal patterning factor-like 9 (EPFL9). The LbCpf1 system displayed a higher number of mutant $\mathrm{T}_{0}$ plants than the Cas9 system. The LbCpf1 system caused a $63 \mathrm{bp}$ deletion compared to the deletion of $37 \mathrm{bp}$ with the Cas9 system [67]. The Cpf1 system displayed $28.2 \%$ and $47.2 \%$ mutation rates in both tobacco and rice, respectively [61]. For targeted gene knock-in, both LbCpf1 and FnCpf1 endonucleases were used via the HDR system in plants. The results showed an $8 \%$ higher insertion efficiency in the LbCpf1 system compared to FnCpf1 in rice [68]. The Cpf1 system has displayed promising results and provides an alternative tool to edit the genome of both model and non-model plant species with more precision. However, there is a need to improve the GET toolkit to achieve greater precision, flexibility, and ease of handling. The BE system is an advanced method for genetic manipulation. 


\subsubsection{The BE System-a Proof of Concept for Crop Improvement}

The BE system was used to investigate the genetic mechanism of plant architecture and to determine how to enhance the efficiency of nutrient use through targeted mutagenesis of SLR1 and NRT1.1B in rice. The mutant plants demonstrated a significant elevation in rice mutant plant height and nutrient use efficiency [69]. Similarly, Ren et al. [70] modified the binary vector by introducing pUbi:rBE3 and pUbi:rBE9 to target the genes OsAOS1, OsJAR1, OsJAR2, and OsCOI2, respectively, in rice. The results demonstrated that the rice base editor 9 (rBE9) resulted in higher editing accuracy and efficiency with lower off-target mutations compared to $\mathrm{rBE} 3$. The rBE9 efficiency increased owing to the presence of UGI from Bacillus subtilis bacteriophage PBS1, which stopped uracil N-glycosylase activity at the $\mathrm{BE}$ site [25]. Zong et al. [71] developed targeted mutagenesis through BE in two genes, TaLOX2 and $A L S$, to develop herbicide-resistant wheat, rice, and potato, using a base editor fusion protein composed of Cas9 nickase and human APOBEC3A (A3A-PBE). The pnCas9-PBE and A3A-PBE showed higher efficiency in the conversion of $\mathrm{C}$ to $\mathrm{T}$ at the target sites of the genes under investigation. Based on the BE proof of concept, Tian et al. [72] successfully modified ZmCENH3 and ALS gene editing in maize and watermelon. Similarly, a major gene, TaALS-P174, was targeted with a mutation efficiency of $75 \%$. Mutant plants showed significantly increased tolerance to the herbicides imidazolinone, sulfonylurea, and the aryloxyphenoxy propionate-type [73]. The novel G. hirsutum BE 3 (GhBE3) introduced point mutations in GhCLA and GhPEBP genes controlling chlorophyll content and demonstrated a mutation frequency of 26.67 to $57.78 \%$ [74]. Li et al. [75] demonstrated the successful application of the ABE system for mutagenesis of ACC, ALS, $C D C 48, D E P 1, N R T 1.1 B$, and OsEV , resulting in a mutation efficiency of $7.5 \%$ in protoplasts and $59.1 \%$ in regenerated mutant rice and wheat plants. Moreover, an endogenous gene was also modified through a gain-of-function mutation, resulting in tolerant rice. Further application of the ABE system was evaluated for IPA1 (OsSPL14), OsSPL17, OsSPL18, and SLR1 genes and was effective in editing these genes through conversion of $\mathrm{A}$ to $\mathrm{T}$ and $\mathrm{G}$ to $\mathrm{C}$ in rice plants [76]. The BE (ABE7.8 and ABE7.10) use for MPK6, MPK13, SERK2, WRKY45, and Tms9-1 genes showed significant on-target efficiency in mutant rice plants [77]. Jin et al. [78] analyzed the mutation efficiency of ABEs compared to CBEs in the OsACC, OsALS, OsDEP1, OsNRT1, OsCDC48, and OsWx genes in rice. The results demonstrated that the CBE system could be used to reduce off-target mutations. Recent developments in the BE system in plant species have been well documented in several independent studies [79-81]. The BE system has contributed significantly to elite germplasm development; however, there are fast-moving developments in GETs, and researchers are moving toward more reliable and easy techniques.

\subsubsection{The PE System-a Proof of Concept for Crop Improvement}

Recently, the PE system has achieved indels from approximately 44 to $80 \mathrm{bp}$ and point mutations with more precision and efficiency. Protoplasts in nine lines of rice and seven lines of wheat showed a mutation efficiency of approximately $19.2 \%$ [82,83]. Hybridization of target DNA-pegRNA PBS and target DNA-reverse transcripts resulted in minimum off-target effects. The application of GETs for crop improvement programs helped to develop germplasms with better yield, enhanced resistance to biotic and abiotic stresses and increased climate resilience (Figure 2). Improved crops can help to ensure food security. Developing NPBTs for crop improvement programs is also of interest to stakeholders, especially to feed growing human populations.

\subsection{GETs for Hybrid Seed Production}

Sustainable food production is challenging because of divergent cultural values, geographical boundaries, environmental factors, and technological differences. However, these difficulties can be resolved, and modern agricultural practices can be adapted to increase productivity per unit area [84]. NPBTs have the potential for effective use in heterosis breeding in agriculturally important crops. The development of hybrid seeds is a 
reality that has contributed significantly to increasing crop production and, ultimately, to income from farms, especially in underdeveloped countries. Hybrid vigor, exhibited in both plants and animals, allows hybrids to perform better than parental lines [85]. Hybrid seed production is achieved through three-, two-, and one-line systems. Each system has certain advantages and disadvantages. The prime importance of hybrid seeds is their higher yield and increased quality, enhanced resistance to biotic and abiotic stressors, and increased environmental resilience [86]. Three-line hybrid seed production systems have been less widely adopted owing to their laborious and time-consuming nature; therefore, two-line and one-line hybrid seed production systems are considered viable under current circumstances. However, the principles of the three hybrid development systems are relevant.

A. First generation GETs

SDODOCOM: $\Rightarrow$ Insertion, Deletion, Substitution, Inversion $\Rightarrow \begin{aligned} & \text { Insertion, Deletion, Substitution, In } \\ & \text { of nucleotides (Random mutation) }\end{aligned}$ Natural or induced mutation (physica or chemical mutagenic agents)

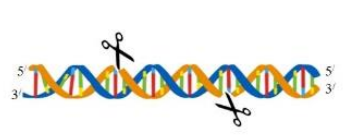

MegaN

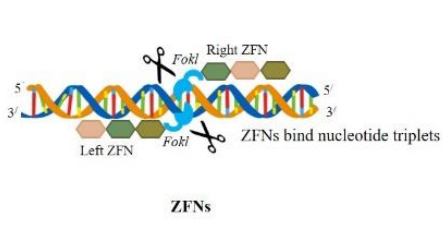

ZFNs

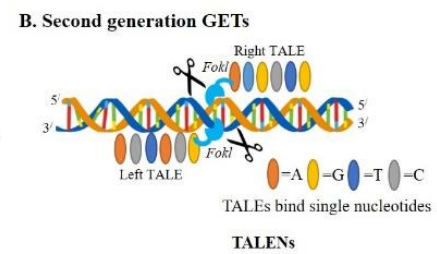

TALENs

MegaN, ZFNs and TALENs are Protein dependent DNA cleavage systems causing non-random mutation

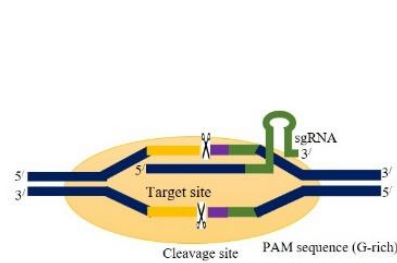

Cas9

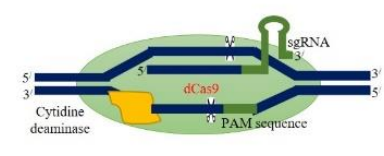

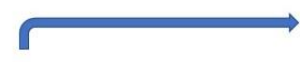

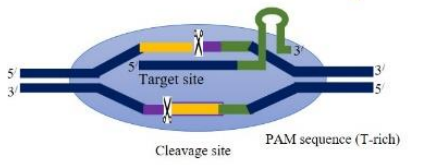

Cpf1

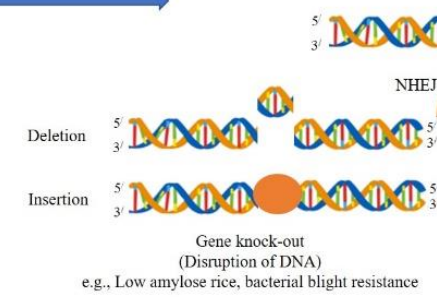

NHEJ

HDR

SODOOOOA:

e.g., Low amylose rice, bacterial blight resistance
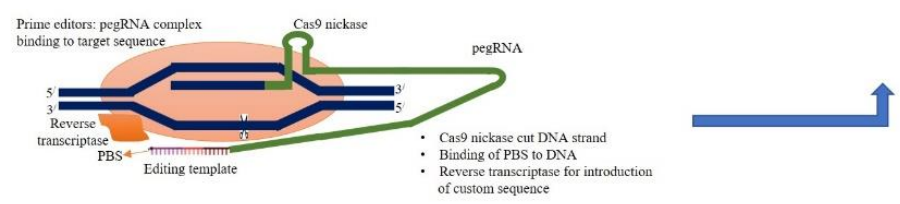

Prime editing

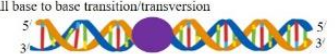

Insertion (1 bp $\geq 80$ bp)

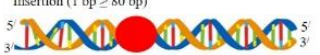

Deletion (1 bp $\geq 44$ bp) 10 .

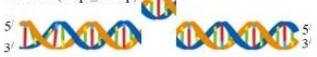

Figure 2. Schematic models of gene editing systems. (A) The first generation included induced mutation through mutagenic agents, Radiations and EMS (Ethyl methanesulfonate), meganuclease (MegaN), and Zinc finger nucleases (ZFNs); (B) second generation included transcription activator-like effector nucleases (TALENs); (C) third generation included the CRISPRassociated protein system 9 (Cas9), the CRISPR system from Prevotella and Francisella1 (Cpf1), BE and PEs. The GETs from MegaN, ZFNs, TALENs, CRISPR/Cas9, Cpf1 generate DSBs. BE and PE create mutations without DSBs. DSB = doublestranded breaks; dCas = catalytically inactive (dead) Cas; PAM = protospacer adjacent motif; PBS = primer binding site; NHEJ = non-homology end joining; HDR = homology-directed repair.

\subsubsection{First Generation Hybrid Development System}

Male sterility (MS) is considered a worthy attribute for the efficient production of premium quality seeds. Therefore, MS systems have been studied and applied to several crop species. MS attributes have been classified into cytoplasmic male sterility and genic male sterility, based on the fertility of the gene source [87]. In the first generation (three-line) hybrid production system, fertility maintenance, and restoration are integral components [88]. 
Prof. Longping Yuan led a joint venture to identify and develop a commercially applicable hybrid production system during the 1960s. The researchers first identified wild male sterile rice varieties carrying the wild abortive cytoplasmic MS (CMS-WA) gene [89]. The CMS-WA gene has been introgressed into several rice lines to produce hybrid rice and is widely adopted in China. Hybrid rice has increased grain yield compared to inbred varieties [90]. In the first generation system, three lines, namely the CMS, maintainer, and restorer, require considerable time and labor to achieve, and commercial CMS limits the selection of parental lines. This influences the genetic diversity and restoration of CMS lines owing to cytoplasmic-nuclear interactions [91]. These limitations restrict the application of CMS systems for hybrid seed production and pave the way for the development and application of NPBTs for hybrid seed production that is more precise and cost-effective.

\subsubsection{Second-Generation Hybrid Development System}

The two-line breeding system, known as second-generation hybrid development, depends on photo/thermosensitive genic MS (P/TGMS) lines under controlled conditions or maintainer lines under non-restricted conditions. The second-generation hybrid development system is convenient, as the manipulation of P/TGMS genes via GETs leads to the generation of MS plants [8]. Several genes controlling P/TGMS have been characterized and cloned in model species, such as rice. The first rice that has the photoperiod genetic male sterile (PGMS) gene was identified in 1973 and named Nongken58S. Nongken58S displayed complete MS characteristics under an extended photoperiod and restored fertility under a short photoperiod. Later, the PGMS character in Nongken58S was controlled via $p m s 1$, pms2, and pms3 [92]. The factor pms3 encodes long non-coding RNA (IncRNA), which is long-day specific male fertility-associated RNA. A thermosensitive genetic male sterility (TGMS) Indica rice line was generated through the transformation of the P/TGMS gene from Nongken58S [93]. The TGMS attribute in Indica rice was controlled by $p / t m s 12-1$, encoding a small RNA13 of 21-nucleotide nucleotides. Carbon-starved anthers (CSA) are associated with reverse photoperiod-sensitive genic MS (rPGMS) rice during short photoperiods and are fertile during long photoperiods. CSA encodes the MYB transcription factor R2R3, which mediates sugar partitioning. Moreover, UDP-glucose pyrophosphorylase1 (Ugp-1) splicing depends on temperature, and overexpression of Ugp-1 causes TGMS in rice [94]. The first Indica TGMS Annong S-1 (AnS-1) rice was identified in 1987. Zhou et al. (2014) studied the TMS5 gene and found that the gene encodes endonuclease RNase ZS1 in AnS-1. The endonuclease RNase ZS1 degrades the temperature-sensitive ubiquitin fusion ribosomal protein L40 (UbL40), which influences TGMS characteristics. The tms5dependent rice line plays an important role in two-line hybrid development [95]. Moreover, further studies identified the presence of a mutation in TMS5 from 24 of 25 commercial MS lines. Barman et al. [8] and Zhou et al. [96] knocked out the TMS5 gene and successfully developed a TGMS line for hybrid seed production. In wheat, identification of the Ms1 gene has provided a platform for novel hybridization strategies. The generation of induced biallelic frameshift mutations in Ms1 resulted in the complete MS wheat cultivar Fielder and Gladius. These selected non-transgenic MS lines helped to produce hybrid wheat. The successful application of Cas9 for P/TGMS-related genes has provided many options for employing Cpf1, BEs, and PEs. The newly available GETs can reduce various negative characteristics, for example, off-target effects and low mutation rates, and also have the ability to generate transgene-free plants in greater numbers. The advent of multiplex genome editing has paved the way to use more sophisticated techniques to achieve the desired objective within minimum time. The simultaneous knockout of multiple genes in a single vector construct has helped to generate a multi-control sterility system.

\subsubsection{Multi-Control Sterility (Third-Generation) Hybrid Development System}

Third-generation hybrid development, known as the multi-control sterility (MCS) system, uses the transgenic method to develop hybrid seeds. The gene ZmMs7 was isolated through fine-mapping and functional characterization and encoded a transcription factor 
PHD-finger orthologous to PTC1 in rice and MS1 in Arabidopsis. The MCS was used to develop a transgenic maintainer line that can be deployed for wheat hybrid seed production. The ms7-6007 transgenic maintainer line was developed through the transformation of the MCS vector construct consisting of (i) the ZmMs7 gene to restore fertility, (ii) $\alpha$-amylase gene $Z m A A$, (iii) the DNA adenine methylase gene Dam to devitalize transgenic pollen, (iv) the red fluorescence protein gene DsRed 2 or $m$ Cherry to mark transgenic seeds, and (v) the herbicide-resistant gene Bar for transgenic seed selection. The transgenic maintainer line is self-pollinated and later produces red fluorescent (transgenic) and normal color seeds (non-transgenic) at a ratio of 1:1. Moreover, the Japonica male sterile mutant, ms26/ms26, was developed through the transformation of male fertile mutants, Ms26, Zm-aa1, and DsRed2, through rice optimized codons. Ms26 encodes cytochrome P450 mono-oxygenase, which further catalyzes $\omega$-hydroxylation of C16 and C18 fatty acids in the tapetum [97]. A large population of maintainer lines has been developed and characterized at both phenotypic and molecular levels. The best perming line (full fertility restoration, singlecopy transgene, 1:1 segregation with viable and non-viable pollen, 1:1 segregation of transgenic and non-transgenic seeds) was selected to enhance environmental and food safety. A novel nuclear MS, O. sativa No Pollen 1 (OsNP1) gene was identified through positional cloning. OsNP1 encodes glucose-methanol-choline-oxidoreductase, which is essential for tapetum degeneration and pollen exine formation [98]. A novel MS rice mutant, Osnp1, was developed through the ethyl methanesulfonate mutagenized gene in the Huanghuazhan cultivar. Similarly, a binary vector was developed containing two separate T-DNAs, namely the NPTII gene with CaMV 35 S promoter and another second T-DNA containing the OsNP1 gene with a native promoter, Zm-aa1 with pollen-specific PG47 promoter, and DsRed with aleurone layer-specific LTP2 promoter. Both of these T-DNAs were transformed to the osnp 1 mutant, and screening and characterization of several transformations led to the identification of a single $\mathrm{T}_{1}$ Zhen18B. The mutant containing the second T-DNA was selected as the maintainer line and displayed normal vegetative and reproductive growth. The selfing of Zhen $18 \mathrm{~B}$ produced a segregated population with transgenic (fluorescent) and non-transgenic (non-fluorescent) plants in a 1:1 ratio. The mutant plants with fluorescence were similar to the Zhen18B maintainer, whereas the non-fluorescent plants were similar to the osnp1 mutant. Thus, selfing and selection among the Zhen18A population provide maintainer lines for commercial hybrid seed production. Zhen18A was used as a female parent, and cross-pollination was performed with approximately 1200 paternal lines. Of the hybrids produced, $85 \%$ displayed a higher yield than the parents; however, $10 \%$ were transgressive segregants. The outcome of the breeding program showed the promising nature of third-generation hybrid seed production. Zhen18A was recently approved by the Crop Variety Appraisal Committee of Guangdong Province. All three generations of hybrid seed development systems are described in Figure 3.

\subsubsection{Induced Apomixis through Genome Editing to Preserve Heterosis}

Heterosis breeding has contributed significantly to improving crop production and ultimately income from farming. However, the segregation of traits in subsequent generations forces farmers to buy costly seeds for each sowing season. NPBTs have addressed this problem through de novo modification of genes controlling sexual reproduction to apomixis, which has been successfully performed in Arabidopsis [99]. Khanday et al. [44] knocked out three genes, $B B M 1, B B M 2$, and $B B M$, which caused embryo arrest and abortion, and the wild-type attribute (fertility) recovered through the male-transmitted BBM1. These findings indicate that fertilization during embryogenesis is mediated by the pluripotency factors transmitted from the male genome. The conversion of mitosis for meiosis $(\mathrm{MiMe})$ phenotype, through genome editing, is combined with the expression of the BBM1 gene in egg cells to obtain clonal progeny, preserving genome-wide parental heterozygosity $[100,101]$. The induced (synthetic) apomixis is heritable in multiple generations of clones and is therefore known as a clonal fix strategy. Wang et al. [102] edited REC8, PAIR1, and OSD1 meiotic genes by multiplexing from hybrid rice, producing clonal diploid gametes 
and tetraploid seeds. Similarly, Kelliher et al. [103] and Li et al. [104] manipulated the MTL locus responsible for fertilization through the CRISPR/Cas9 system and obtained haploid maize hybrid seeds. The editing of endogenous genes, OsSPO11-1, OsREC8, OsOSD1, and OsMAT, resulted in the MiMe phenotype [105]. The application of GETs for the preservation of hybrid vigor in rice proved to be a proof of concept for possible use in other crops, ultimately lowering the cost of production. However, the number of viable clones with intact heterosis is limited. To date, only $30 \%$ of seeds with intact $F_{1}$ properties have been reported in the $\mathrm{F}_{2}$ generation. Underlying pathways controlling the MiMe phenotype to increase the percentage of seeds with intact hybrid vigor in $\mathrm{F}_{2}$ should be explored further. Moreover, the efficiency and accuracy of genomic alternation of genes controlling the MiMe phenotype can be increased through the use of BEs and PEs. The application of GETs for crop improvement and hybrid seed production has greatly enhanced the average yield per hectare. However, several countries have adopted regulatory regimes limiting their global application.

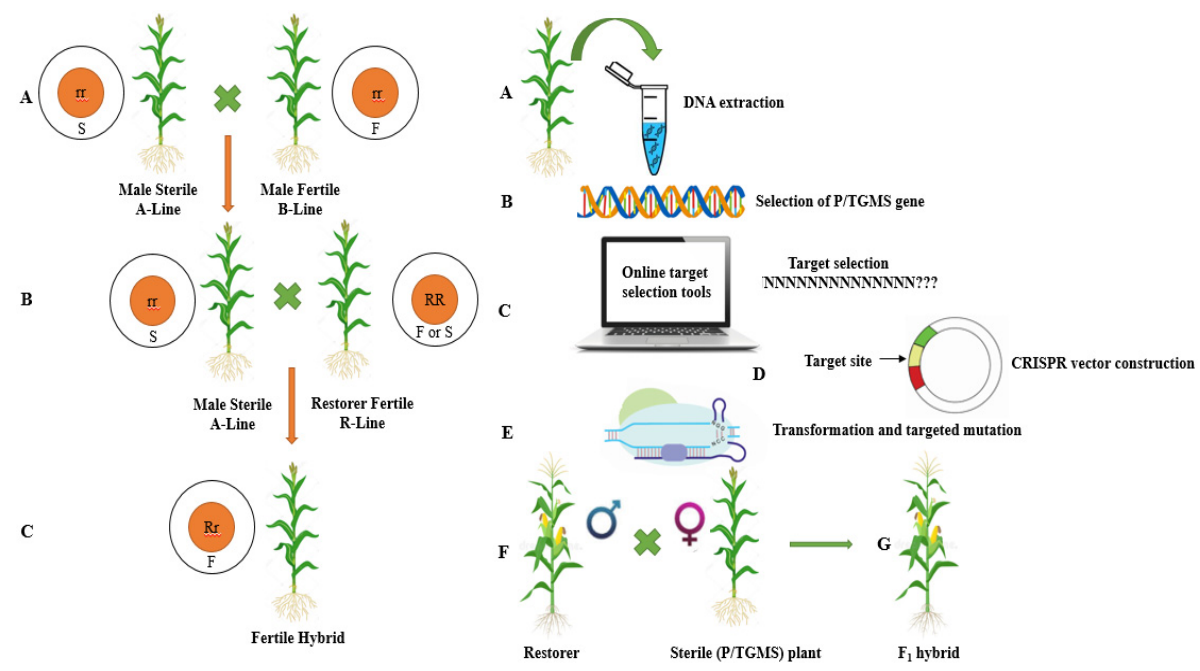

A: First Generation

B: Second Generation

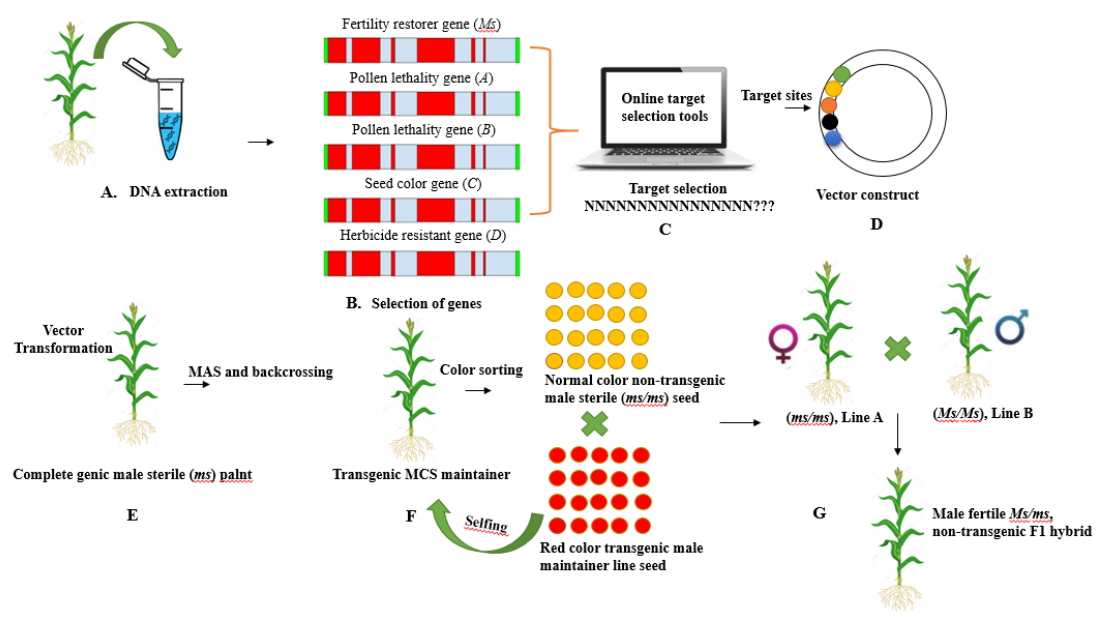

C: Third Generation

Figure 3. Schematic description all three generations of hybrid development. (A) First generation or three-line hybrid development system consisting of A (male sterile), B (male fertile), and R (restorer) lines; (B) second-generation or two-line hybrid development system through targeted mutagenesis of the P/TGMS gene, later crossed with restorer line; (C) third generation or MCS system through multiplexing of genes controlling MS, pollen lethality and color sorting. The mutants are backcrossed with selfing of the MCS maintainer line to develop desirable plants. 


\section{GETs for Improved Grain Quality}

Improvement in the quality of grain is a key attribute for plant breeders. It is a quantitative trait that is simultaneously influenced by various factors, including environmental ones. In recent years, breeding efforts for semi-dwarf varieties and heterosis have contributed significantly to achieving high yield, but with low quality, and this aspect has been the subject of much research [106]. The availability of genome sequencing data for several model and non-model species has facilitated novel gene identification, targeted genome modification, and functional characterization of genes controlling grain quality traits. To date, little success has been achieved through the application of genetic markers to identify the genomic regions controlling grain quality-related traits. Researchers are now using NPBTs for large-scale and rapid evaluation of traits in various plant populations. The GETs have contributed significantly to the development of premium quality cultivars within a short time period.

\section{GETs Proof of Concept for Grain Quality Improvement}

The hybrid rice (Indica), grown in mainland China, has a high amylose content (AC), which makes the grains dry and hard when cooked. The AC is controlled mainly by the Waxy (Wx) gene. Ma et al. [107] manipulated the $W x$ gene through the CRISPR/Cas9 system in the Japonica cultivar, and the mutant displayed reduced AC. Moreover, Zhang et al. [108] and Li et al. [109] used the same genome editing system to generate functional mutations in Japonica cultivars "Xiushui134" and "Wuyunjing 7". These mutations helped to reduce AC mutants without compromising agronomic traits. The genetic factors SBEI and SBEII play an effective role in determining the physical properties and the fine structure of starch. The CRISPR/Cas9 system was employed to manipulate both SBEI and SBEII, which displayed the underlying role of $S B E I I$ in the creation of high AC rice. The $B A D H 2$ gene is responsible for controlling the fragrance in rice through the deposition of substrate 2AP. The 8-bp mutation in the BADH2 gene resulted in a higher accumulation of $2 \mathrm{AP}$ substrate in the resulting genotypes [110]. Rice contains six 5-methylcytosine (5mC) DNA methylase genes (OsROS1, OsROS1b, OsROS1c, OsROS1d, OsDML3a, and OsDML3b) that contribute significantly to the nutritional quality of the grains. It is possible to manipulate these genes through GETs to develop germplasms with improved nutritional quality (Table 2). The storage protein in wheat, gluten, can cause health issues in consumers, such as celiac and non-celiac disease and gluten ataxia. The gene controlling $\alpha$-gliadin was knocked out through the CRISPR/Cas9 system. Screening for transgene-free and off-target mutagenesis found that the mutants with reduced gluten content could be further used for breeding low-gluten wheat cultivars [111]. Targeted mutagenesis of GW2 controlling RING-type E3 ubiquitin ligase assisted in developing an understanding of the regulatory mechanism of cell numbers in spikelet hulls in increasing the crude protein content of wheat, together with the increased weight of grains [112]. RNA interference (RNAi) and the CRISPR/Cas9 system were employed to manipulate the ZmMADS47 gene by controlling a MAD-box protein interacting with $\mathrm{O}_{2}$ to activate the zein gene promoter. The mutant developed through RNAi showed a zein content of $16.8 \%$, whereas the MADS/CAS9-21 mutant showed a zein content of $12.5 \%$ [113]. The disruption of the $W x 1$ gene controlling granule-bound starch synthase through the Cas 9 system generated several versions of $W x$ mutants, which can be further used for various purposes, especially crossbred as CRISPRwaxy hybrids [114]. Researchers at DuPont successfully manipulated the ARGOS8 gene to develop drought-resilient maize. The knocking of the native GOS2 promoter into the $5^{\prime}$ untranslated region ARGOS8 generated maize mutants with better yield under waterlimited conditions. 
Table 2. List of genes edited through the application of CRISPR/Cas9, Cpf1, base editing, and prime editing systems in plants.

\begin{tabular}{|c|c|c|c|c|c|c|}
\hline Specie. & GET System & Trait of Interest & Gene Function & Target Gene & $\begin{array}{l}\text { Transformation } \\
\text { Method }\end{array}$ & Reference \\
\hline \multirow[t]{29}{*}{ Oryza sativa $\mathrm{L}$. } & CRISPR/Cas 9 & $\begin{array}{l}\text { Yield and quality } \\
\text { improvement }\end{array}$ & Increases length and yield & OsPPKL1 & Agrobacterium & [115] \\
\hline & & & $\begin{array}{l}\text { A key enzyme of aromatic } \\
\text { amino acids biosynthesis }\end{array}$ & EPSPS & $\begin{array}{c}\text { Biolistic } \\
\text { transformation }\end{array}$ & [116] \\
\hline & & & $\begin{array}{l}\text { Regulators of inflorescence } \\
\text { Architecture of plant height }\end{array}$ & $D E P 1$ & Agrobacterium & [48] \\
\hline & & & High amylose & SBEIIb & Electroporation & [117] \\
\hline & & & Amylose content & Waxy & Agrobacterium & [108] \\
\hline & & & $\begin{array}{l}\text { Isoamylase-type } \\
\text { debranching enzyme }\end{array}$ & ISA1 & Agrobacterium & [118] \\
\hline & & & $\begin{array}{l}\text { Negative regulator of } \\
\text { thermosensitive } \\
\text { genicmale sterility }\end{array}$ & TMS5 & Agrobacterium & [96] \\
\hline & & & Low phytic acid & OsITPK6 & Agrobacterium & [119] \\
\hline & & & Enhanced fragrance & Badh2 & Agrobacterium & [110] \\
\hline & & & Grain weight & GW2, & Agrobacterium & [49] \\
\hline & & & Grain weight & TGW6 & Agrobacterium & [49] \\
\hline & & & Grain weight & GW5, & Agrobacterium & [49] \\
\hline & & & $\begin{array}{l}\text { Early maturity of } \\
\text { rice varieties }\end{array}$ & $H d 2$ & Agrobacterium & [120] \\
\hline & & & $\begin{array}{l}\text { Early maturity of } \\
\text { rice varieties }\end{array}$ & Hd4 & Agrobacterium & [120] \\
\hline & & & $\begin{array}{l}\text { Early maturity of } \\
\text { rice varieties }\end{array}$ & Hd5 & Agrobacterium & [120] \\
\hline & & & $\begin{array}{l}\text { Improved growth } \\
\text { and productivity }\end{array}$ & PYLs & Agrobacterium & [121] \\
\hline & & Biotic stresses & $\begin{array}{c}\text { Various abiotic stress } \\
\text { tolerance and } \\
\text { disease resistance }\end{array}$ & OsMPK5 & Agrobacterium & [122] \\
\hline & & & $\begin{array}{l}\text { Rice blast resistance } \\
\text { negative regulator }\end{array}$ & ERF922 & Electroporation & [50] \\
\hline & & & $\begin{array}{l}\text { Resistance to rice } \\
\text { tungrospherical virus }\end{array}$ & eIF4G & Agrobacterium & [123] \\
\hline & & & $\begin{array}{l}\text { A key enzyme for the } \\
\text { biosynthesis of } \\
\text { branched-chain amino } \\
\text { acids (major targets } \\
\text { for herbicides) }\end{array}$ & $A L S$ & Agrobacterium & [124] \\
\hline & & & Salinity tolerance & OsRR22 & Agrobacterium & [125] \\
\hline & & & $\begin{array}{c}\text { Various abiotic stress } \\
\text { tolerance and } \\
\text { disease resistance }\end{array}$ & OsMPK5 & Agrobacterium & [122] \\
\hline & & $\begin{array}{c}\text { Nutritional } \\
\text { improvement }\end{array}$ & Low Cd-accumulation & OsNramp5 & Agrobacterium & [54] \\
\hline & & & $\begin{array}{c}\text { Potassium } \\
\text { deficiency tolerance }\end{array}$ & OsPRX2 & Agrobacterium & [126] \\
\hline & & & Low cesium accumulation & OsHAK-1 & Agrobacterium & [127] \\
\hline & CPf1 & Yield and quality & Grain length-yield & OsGS3 & Agrobacterium & [66] \\
\hline & & & Leaf and yield & OsDEP1 & Agrobacterium & [64] \\
\hline & & & Grain yield & OsNAL & Agrobacterium & [66] \\
\hline & & & Floral organ identity & $O s D L$ & Agrobacterium & [61] \\
\hline
\end{tabular}


Table 2. Cont.

\begin{tabular}{|c|c|c|c|c|c|c|}
\hline Specie. & GET System & Trait of Interest & Gene Function & Target Gene & $\begin{array}{l}\text { Transformation } \\
\text { Method }\end{array}$ & Reference \\
\hline & & & $\begin{array}{l}\text { Negatively modulates } \\
\text { bulliform cells }\end{array}$ & OsROC5 & Agrobacterium & {$[64,128]$} \\
\hline & & Abiotic stress & $\begin{array}{c}\text { Carotenoid } \\
\text { biosynthetic pathway }\end{array}$ & OsPDS, & Agrobacterium & [109] \\
\hline & & & Herbicide resistance & OsALS & Agrobacterium & [78] \\
\hline & & & $\begin{array}{l}\text { Abscisic acid } \\
\text { regulation-stress tolerance }\end{array}$ & OsNCED1 & Agrobacterium & [61] \\
\hline & & & $\begin{array}{l}\text { Caroteniod catabolism and } \\
\text { abscisic acid metabolism- } \\
\text { stress tolerance }\end{array}$ & OsAO1 & Agrobacterium & [61] \\
\hline & & & Abiotic stress tolerance & EPFL9 & Agrobacterium & [67] \\
\hline & & & Herbicide resistance & OsBEL & Agrobacterium & [65] \\
\hline & & & Herbicide resistance & OsRLK & Agrobacterium & [65] \\
\hline & BEs & Yield and quality & Amylose content & OsWaxy, & Agrobacterium & [129] \\
\hline & & & Spikelet and floral organ & $S N B$ & Agrobacterium & [130] \\
\hline & & & Grain shape & SLR1, & Agrobacterium & [130] \\
\hline & & & Male fertility & Tms9-1, & Agrobacterium & [130] \\
\hline & & & Grain weight & OsSPL14, & Agrobacterium & [130] \\
\hline & & & Grain size & OsSPL17, & Agrobacterium & [130] \\
\hline & & Biotic stress & Rice blast resistance gene & Pid3 & Agrobacterium & [131] \\
\hline & & $\begin{array}{l}\text { Nitrogen transport } \\
\text { and leaf death }\end{array}$ & Nitrogen transport & OsACC1, & Agrobacterium & [130] \\
\hline & & & Nitrogen transport & OsNRT1, & Agrobacterium & [78] \\
\hline & & & Leaf senescence & OsCDC48, & Agrobacterium & [78] \\
\hline \multirow[t]{13}{*}{$\begin{array}{l}\text { Triticum } \\
\text { aestivum }\end{array}$} & CRISPR/CAS9 & Yield and quality & $\begin{array}{c}\text { Grain weight } \\
\text { negative Regulator }\end{array}$ & TaGW2 & $\begin{array}{c}\text { Biolistic } \\
\text { transformation }\end{array}$ & [58] \\
\hline & & & Low-gluten & Alpha-gliadin & $\begin{array}{c}\text { Biolistic } \\
\text { transformation }\end{array}$ & [111] \\
\hline & & & $\begin{array}{l}\text { Control grain length } \\
\text { and weight }\end{array}$ & TaGASR7 & $\begin{array}{c}\text { Biolistic } \\
\text { bombardment }\end{array}$ & [132] \\
\hline & & Biotic stress & Mildew-resistance locus & TaMLO & Agrobacterium & [133] \\
\hline & & & $\begin{array}{c}\text { Powdery } \\
\text { mildew-resistance negative } \\
\text { regulator }\end{array}$ & TaMLO-A1 & $\begin{array}{c}\text { Biolistic } \\
\text { bombardment }\end{array}$ & [134] \\
\hline & & & $\begin{array}{l}\text { Disease resistance against } \\
\text { powdery mildew }\end{array}$ & TaEDR1 & $\begin{array}{c}\text { Biolistic } \\
\text { transformation }\end{array}$ & [135] \\
\hline & & Abiotic stress & Fe content & TaVIT2 & $\begin{array}{c}\text { Biolistic } \\
\text { bombardment }\end{array}$ & [136] \\
\hline & BEs & Yield and quality & $\begin{array}{l}\text { Control grain size } \\
\text { and weight }\end{array}$ & TaGW2 & Agrobacterium & [75] \\
\hline & & & $\begin{array}{l}\text { Inflorescence architecture } \\
\text { and affects panicle growth } \\
\text { and grain yield }\end{array}$ & TaDEP1, & Agrobacterium & [75] \\
\hline & & $\begin{array}{c}\text { Biotic and } \\
\text { Abiotic stress }\end{array}$ & $\begin{array}{l}\text { repress resistance pathway } \\
\text { to powdery mildew }\end{array}$ & TaLOX2 & $\begin{array}{c}\text { Particle } \\
\text { bombardment }\end{array}$ & [137] \\
\hline & & & Herbicides resistance & TaALS, & $\begin{array}{c}\text { Particle } \\
\text { bombardment }\end{array}$ & [138] \\
\hline & PEs & Yield and quality & $\begin{array}{l}\text { Control grain length } \\
\text { and weight }\end{array}$ & TaGW2 & Agrobacterium & [82] \\
\hline & & & $\begin{array}{l}\text { A gibberellin regulated } \\
\text { gene that controls } \\
\text { grain length }\end{array}$ & TaGASR7 & Agrobacterium & [82] \\
\hline
\end{tabular}


Table 2. Cont.

\begin{tabular}{|c|c|c|c|c|c|c|}
\hline Specie. & GET System & Trait of Interest & Gene Function & Target Gene & $\begin{array}{l}\text { Transformation } \\
\text { Method }\end{array}$ & Reference \\
\hline & & Biotic stress & $\begin{array}{l}\text { Repress resistance pathway } \\
\text { to powdery mildew }\end{array}$ & TaLOX2 & Agrobacterium & [82] \\
\hline & & & Mildew-resistance locus & TaMLO, & Agrobacterium & [82] \\
\hline \multirow[t]{9}{*}{ Zea mays } & CRISPR/Cas9 & Yield and quality & 45 (male sterility) & MS45 & $\begin{array}{c}\text { Biolistic- } \\
\text { mediated } \\
\text { transformation }\end{array}$ & [139] \\
\hline & & & $\begin{array}{l}\text { Increased grain yield under } \\
\text { drought stress }\end{array}$ & ARGOS8 & Agrobacterium & [60] \\
\hline & & & Phytoene synthase & PSY1 & Agrobacterium & [140] \\
\hline & & & Seed and leaves traits & ZmIPK1A, & Agrobacterium & [59] \\
\hline & & & Seed and leaves traits & ZmIPK & Agrobacterium & [59] \\
\hline & & & Seed and leaves traits & $Z m M R P 4$ & Agrobacterium & [59] \\
\hline & & Abiotic stress & $\begin{array}{l}\text { A key enzyme for the } \\
\text { biosynthesis of } \\
\text { branched-chain amino } \\
\text { acids (major targets } \\
\text { for herbicides) }\end{array}$ & ALS2 & Agrobacterium & [139] \\
\hline & CPf1 & Yield and Quality & Cuticular lipids & $\begin{array}{l}\text { Maize glossy2 } \\
\text { gene }\end{array}$ & Agrobacterium & [63] \\
\hline & BEs & & & $\mathrm{ZmCENH3}$ & Agrobacterium & [137] \\
\hline
\end{tabular}

A third-generation base editor (BE3), APOBEC1-XTEN-nCas9-UGI, was employed in rice to test its feasibility and efficiency. Three targets were chosen: one target (P2) in OsPDS, which encodes a phytoene desaturase, and two targets (S3 and S5) in OsSBEIIb, which encode a starch branching enzyme IIb in rice. We delivered the vectors into rice calli through Agrobacterium-mediated transformation. The results displayed precise point mutations at three target sites in rice, thus providing a feasible and effective tool for targeted BE to improve nutritional quality [109]. Similarly, an efficient A.T to G.C BE system was employed in rice. The A.T to G.C mutation resulted in the desired amino acid substitution or potential interference of miRNA binding in the target regions of the $W x$ gene. The mutation frequency induced by the $\mathrm{pHUN} 411-\mathrm{ABE}$ vector was $<10 \%$ at the $W x$ and GL2 targets [141]. To date, the CRISPR/Cas9 system has been widely deployed for improvement in the quality of the grain, but novel Cas9 variants (e.g., Cpf1, BE, and PE) have immense potential for improving grain quality. These variants demonstrate superior results with less chance of off-target effects and higher numbers of transgene-free plants.

\section{Multiplex Genome Editing for Complex Traits}

Metabolic pathways are responsible for economically important traits in plants. These metabolic pathways are controlled by complex genetic networks within cellular systems. Therefore, molecular techniques with the ability to handle several loci are worthy of both basic and applied research [142]. GETs allow the genetic manipulation of several genes through multiplexing, that is, editing multiple target sites [143]. Multiple gRNAs were assembled in the Golden Gate cloning or Gibson Assembly method, driven by different promoters [144]. Xie et al. [145] employed a simple strategy to engineer endogenous tRNA through a simple, efficient method of editing multiple loci using the CRISPR/Cas9 system. The CRISPR/Cpf1 system has a dual nuclease that cleaves targeted DNA and its own CRRNA [146]. Wang et al. [65] demonstrated the feasibility of multiplex editing in rice using the Cpf1 system. The metabolic engineering of OsGSTU, OsMRP15, and OsAnP responsible for the transport and accumulation of anthocyanin were mutated simultaneously in a rice line with purple leaves to generate green leaf mutants [107]. Similarly, Ma et al. [107] targeted three sites on the OsWaxy gene in rice and generated a mutant with an AC content 
reduced from $14.6 \%$ to $2.6 \%$. Li et al. [147] edited five genes in the tomato plant that controlled the carotenoid biosynthesis pathway, using six gRNAs matching two targets in the SGR1 gene and one each in the genes $L C Y-E, B l C, L C Y-B 1$, and LCY-B2. All of these accumulated more lycopene than wild-type tomato plants. GW2, GW5, and TGW6 in rice were edited simultaneously with three different gRNAs to introduce simple indels via the NHEJ pathway. Genes controlling grain weight have also been targeted [49]. The multiplex editing system helped to knock out various genes, for example, Brassinosteroid Insensitive 1, Jasmonate-Zim-Domain Protein 1, and Gibberellic acid insensitive in Arabidopsis and Rice Outermost Cell-specific gene 5, Stromal Processing Peptidase, and Young Seedling Albino in rice, and successfully obtained the desired phenotypes [148]. Multiplex editing has been actively used to induce mutations in numerous loci in plant genomes and is considered a reliable tool for precise genome modification

\section{Challenges and Future Perspectives}

The revolution in the field of molecular biology and the discovery of the CRISPR sequence in the microbial immune system has allowed biotechnologists to induce mutations in any genome of interest with specificity and efficiency. These NPBTs have provided scientists with the ability to achieve the precise and speedy manipulation of desirable traits compared to conventional breeding methods. Advancements parallel to GETs provide valuable opportunities to exploit existing genetic resources to develop crop varieties with premium yield, high nutrition, and resistance to biotic and abiotic stresses. Although GETs have several advantages over classical plant breeding protocols, they also face challenges in their application in agricultural crops. Molecular-level studies are challenging in nonmodel plant species because of the difficulty in identifying loci controlling important traits [149]. Genome sequencing in non-model crops has enabled researchers to identify the genes controlling important phenotypes. Plant species lacking reference genome can be target sequenced using degenerate primers to predict the putative function of traits of interest (Figure 4).

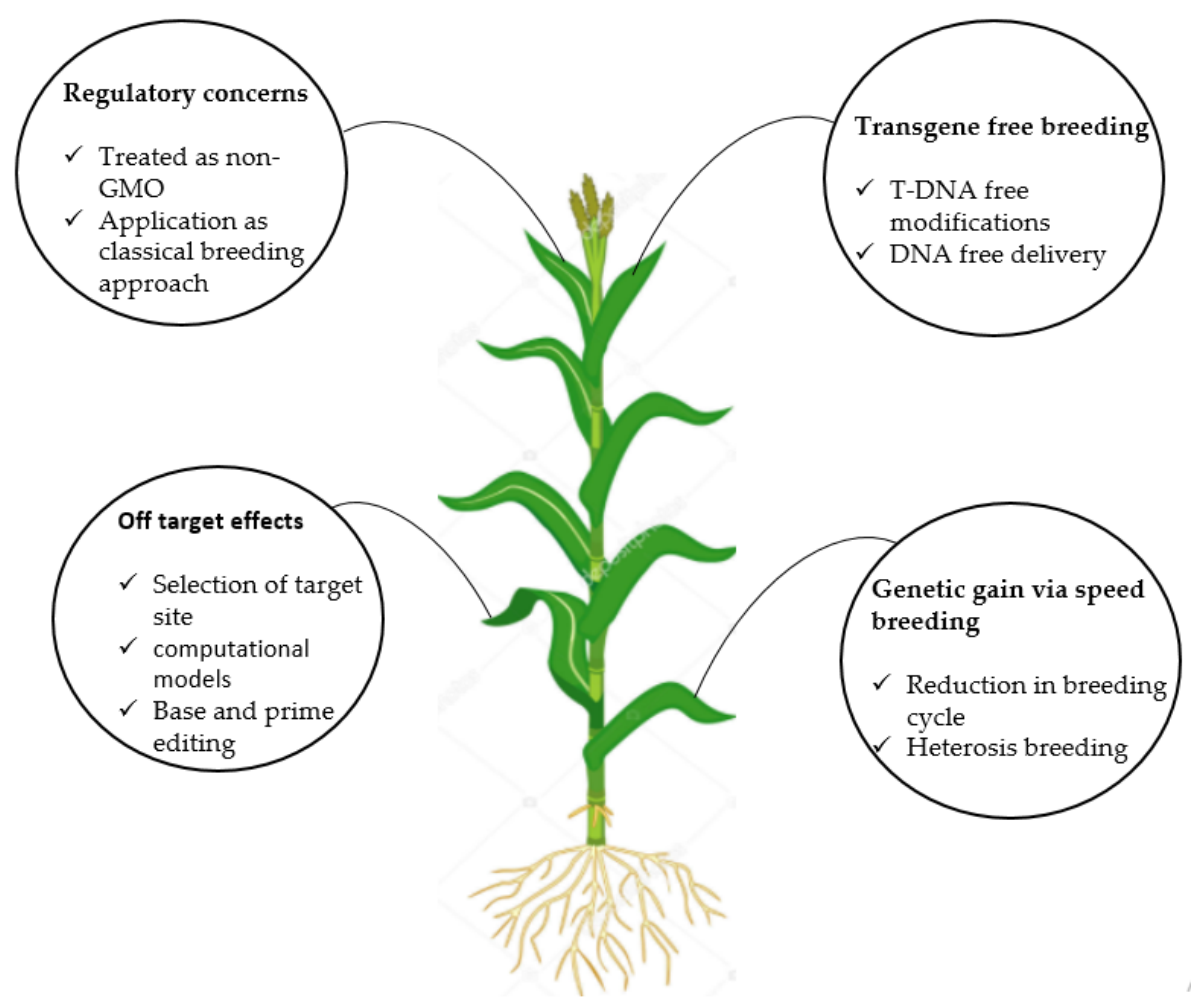

Figure 4. Future perspectives of novel plant breeding techniques for genetic modification in plants genome. 


\subsection{Regulatory Concerns Regarding Genome Editing for Crops and Derived Products}

The debate on GM and genome editing for crops require governmental intervention to formulate clear and uniform regulatory policies. Although the Cartagena Protocol on Biosafety advanced an understanding of the international trade of GM organisms and plants, many governments have divergent opinions on development, commercialization, production, and consumption thereof [150]. Presently, genome editing for crops falls within the ambit of two regulatory guidelines, i) process-based and ii) product-based [151,152]. Moreover, the regulation of genome editing for crops varies between countries. Some nations deal with genome editing for crops as GM, while others deal with such crops as non-GM [151]. For instance, the governments of the United States of America and Brazil have agreed to regulate genome editing for crops in a similar manner to those developed by conventional breeding [114]. The Canadian regulatory guidelines state that any plant-based technology aimed at developing new attributes must comply with the Canadian Food Inspection Agency regulations [153]. The Court of Justice of the European Union (ECJ) has declared that crops produced via NPBTs must be regulated in the same way as GMOs. However, traditional mutagenic techniques with established biosafety records are exempted [154]. To ensure adequate risk assessment and management, the State Council of China has formulated the "Regulation on Administration of Agricultural Genetically Modified Organisms Safety" and has categorized genome editing with GM crops [155]. Similarly, the Indian, Japanese, and New Zealand regulatory bodies categorize genome editing for crops as similar to GM and apply strict biosafety guidelines $[156,157]$. Regulations to deal with genome editing for crops are largely dependent on the existing regulatory framework within a particular country. The advancement in GETs to produce transgene-free plants may assist in circumventing enforced biosafety-related regulations followed for conventional transgenic plants [152]. In summary, it is the responsibility of all stakeholders to debate the regulatory framework further and to develop uniform regulations that promote the safety of humans, animals, plants, and the environment.

\subsection{Transgene-Free Breeding}

The advent of transgene-free breeding has highlighted numerous options for targeted genetic modification without genome disorders [158]. Organisms modified through DNAfree editing are considered non-GMOs in the traditional understanding of plant biology and biotechnology [159]. There has been a focus on three approaches for Cas9/gRNA delivery to achieve DNA-free editing. The most popular method is the delivery of an in vitro assembled RNA. A variation of this approach is the formation of more complex nanostructures that are non-identical to virus-like particles [160]. Nanoparticles allow the delivery of premade protein-RNA complexes and the incorporation of mRNA and gRNA for successful expression of Cas9, followed by the assembly of Cas9/gRNA in the plant cell and subsequent transgene-free editing [161]. Moreover, nanoparticles allow for improvements in cargo stability and delivery efficiency. The second approach is to employ a virus-mediated delivery of encoding RNA templates. Engineering viruses with the CRISPR/Cas system for transgene-free plant genome editing is a significant challenge because of restrictions related to viruses. However, the delivery of the whole CRISPR/Cas9 system in plants has only recently been made possible, using virus vectors. Ma et al. [162] successfully delivered the complete CRISPR/Cas9 cassette in Nicotiana benthamiana, thus obtaining transgene-free genome-edited plants with sufficiently high efficiency. The in vivo processing approach developed by Cody and Scholthof [163] might be the key to designing novel DNA-free editing methods. The third approach is the most intriguing. It is an implementation of the Agrobacterium tumefaciens type IV secretory system for Cas9 delivery as a protein into plant cells. Through the application of these delivery systems, the DNA-free editing approach has been successfully applied to a number of species. A review by Metje-Sprink et al. [164] reports that researchers have achieved transgene-free editing in N. benthaminiana [162], Solanum tuberosum [165], T. aestivum, and Z. mays [166,167], Brassicaceae [168], O. sativa [169], Musa acuminata [170], Lactuca sativa [171], and Piper nigrum [172]. However, this method 
has some drawbacks. The first is the low editing efficiency compared to other delivery approaches. This may be improved by engineering the bacterial delivery mechanisms. Nevertheless, the use of Agrobacterium for DNA-free delivery of at least the protein component is a fascinating achievement with great potential. Its use to deliver base editors for gene editing is yet another confirmation of new possibilities in DNA-free editing [173]. It is noteworthy that in all reported species, transgene-free editing has resulted in inheritable modifications, regardless of the delivery system used. The ability to generate transgenefree plants can help circumvent strict regulatory regimes adopted by several countries for genome editing of crop plants.

\subsection{Off-Target Effects}

CRISPR/Cas9 is a state-of-the-art technology, and the targeting specificity of Cas9 is believed to be tightly controlled by the 20-nt guide sequence of the sgRNA and the presence of a PAM adjacent to the target sequence in the genome. However, potential off-target cleavage activity could still occur on DNA sequences with even three to five bp mismatches in the PAM-distal part of the sgRNA-guiding sequence. The high frequency of off-target activity ( $\geq 50 \%$ ) of RNA-guided endonuclease-induced mutations at sites other than the intended on-target sites is a major concern [174]. Cas9 specificity is much higher in bacteria (small genome size) than in eukaryotes (large genome size). Cas9 in bacteria has evolved without selection pressure; there is thus a high chance of off-target effects in a genome larger than the bacteria [175]. So far, different strategies, such as GC content, gRNA length, truncated gRNA, and chemical modification, have been developed to reduce off-target effects. Along with these methods, computational models for the selection of optimal DNA targets and the corresponding sgRNAs have displayed minimum off-target effects. However, the development of computational efforts requires a more extensive database for different experimental conditions, including different cell types and species. Additionally, Cas variants, for example, BE and PE, are also critical for reducing off-target effects $[28,43]$. The ever-increasing developments in GETs can not only reduce the off-target effect but also increase the on-target efficiency.

\subsection{Genetic Gain Through Speed Breeding}

NPBT allows researchers to use gene bank accessions and mutant collections for gene discovery and deployment. Speed breeding reduces the number of cycles required to produce crop varieties. The extended photoperiod and controlled temperature regimes for rapid generation cycling in fully enclosed glasshouses for large-scale application in crop breeding programs are used. Under traditional varietal development procedures, a $2 \%$ genetic gain (2050 food demand challenge) is a huge challenge for numerous reasons, such as a narrow genetic base, low harvest index, and a lack of elite breeding stock, especially in developing countries with dense populations [176]. The genetic gain was calculated using the following equation:

$$
\Delta G=i \times h \times \sigma A / L
$$

$i=$ selection intensity

$\boldsymbol{h}=$ square root of narrow-sense heritability

$\sigma A=$ square root of additive genetic variance

$L=$ length of breeding cycle

$L$ holds immense importance in achieving genetic gains through the introduction of novel desirable alleles through rapid breeding cycles. Four to seven generations per year have been reported in various crop species, such as wheat, durum wheat (Triticum turgidum), barley (Hordeum vulgare), chickpea (Cicer arietinum), pea (Pisum sativum), and canola (Brassica napus) [177]. Moreover, the vegetative growth period was successfully achieved by establishing short days when growing maize and rice to trigger the reproductive stage under greenhouse conditions. The promising nature of speed breeding not only helps in the study of the genetic aspects but also the introgression of favorable alleles into elite germplasm. Moreover, genomic selection has been demonstrated as a promising breed- 
ing strategy to accelerate genetic gain for heterosis breeding [178-180]. The large-scale genotyping of breeding material through SNP chips and next-generation sequencing has enabled easier and more cost-effective genomic selection. The integration of these novel developments holds the ability to achieve the genetic gain objective within minimum time and with more precision.

\section{Conclusions}

In view of rapid developments in agriculture, especially with respect to plant breeding, there is a need to develop an integrated mechanism for the use of these technologies in service to humanity. The use of GETs with speed breeding can greatly reduce the duration of the breeding cycle, and omics generated data can enhance the efficiency of identifying genes and their potential role in pathways controlling traits of significance. The identified genes can be knocked in and/or out through GETs, ultimately promoting precision in plant breeding. Recent developments in GETs, such as BEs and PEs, have resolved several concerns raised by regulatory bodies. The generation of transgene-free plants is helpful in categorizing genome editing of plants developed through classical breeding methods. The generation of transgene-free plants has significantly increased in BEs and PEs, and the application of speed breeding for genome editing material can further increase the number of transgene-free plants within a short period of time. Recently, the application of nanoparticles has taken place for efficient vector delivery into the host genome. The nanoparticles provided safe, efficient, and direct cytosolic/nuclear Cas-RNPs delivery in any type of cell, with lower off-target mutation compared to plasmid-based CRISPR systems; however, food security concerns in developed and developing nations must be central to the research. However, there is still a quest to develop more efficient, reliable, and cost-effective systems to develop germplasm as per human requirements. In conclusion, global food security must be based on innovations taking place in the present to meet future needs. It also requires the development of a framework based on lessons learned. Therefore, to exploit the full potential of NPBTs, a multipronged approach is needed that encompasses technology development, dissemination of information, adoption of research outcomes, and social acceptance of the product. It is stated with confidence that NPBTs are powerful enough to resolve the global hunger crisis, and the global scientific community must exploit this opportunity by developing NPBT user-friendly regulatory frameworks and support mechanisms.

Author Contributions: S.F. and S.A. conceived the idea and collected the literature review. S.A., A.R., S.S. and S.F. provided technical expertise to strengthen the basic idea. S.F. prepared illustrations, K.-H.J., S.A. and F.M.-P. streamlined the idea. F.M.-P. and K.-H.J. proofread and provided intellectual guidance. All authors have read and agreed to the published version of the manuscript.

Funding: This work was supported by grants from the New Breeding Technology Center Program (PJ01492703 to K-HJ), the Rural Development Administration, Republic of Korea and the National Research Foundation (NRF), and Ministry of Education, Science and Technology (2021R1A2C2010448 to J-KH) and the Chilean National Fund for Scientific and Technological Development (FONDECYT) grant number 1201973.

Institutional Review Board Statement: Not applicable.

Informed Consent Statement: Not applicable.

Data Availability Statement: Not applicable.

Acknowledgments: The authors apologize for being unable to cite the scientific contribution of several researchers in the present review due to limited space. Moreover, we acknowledge Yuan Longping (Late, 22 May 2021) for his services for hybrid rice production with high yield potential. His contribution for agricultural sciences ensured food security for a large number of human population. Yuan being the father of hybrid rice will be remembered among the scientific community.

Conflicts of Interest: The authors declare that the research was conducted in the absence of any commercial or financial relationships that could be construed as a potential conflict of interest. 


\section{References}

1. FAO; IFAD; UNICEF; WFP; WHO. The State of Food Security and Nutrition in the World: Safeguarding against Economic Slowdowns and Downturns; Food and Agriculture Organization: Quebec City, QC, Canada, 2019.

2. Fanzo, J.; Hawkes, C.; Udomkesmalee, E.; Afshin, A.; Allemandi, L.; Assery, O.; Chen, K. 2018 Global Nutrition Report: Shining a Light to Spur Action on Nutrition; Development Initiatives Poverty Research Ltd.: Bristol, UK, 2018.

3. UN. World Population Prospects; United Nations Publications: New York, NY, USA, 2012.

4. Baulcombe, D. Reaping Benefits of Crop Research. Science 2010, 327, 761. [CrossRef] [PubMed]

5. Meemken, E.-M.; Qaim, M. Organic Agriculture, Food Security, and the Environment. Annu. Rev. Resour. Econ. 2018, 10, 39-63. [CrossRef]

6. Bhargava, A.; Srivastava, S. Participatory Plant Breeding: Concept and Applications; Springer: Berlin, Germany, 2019.

7. Sedeek, K.E.M.; Mahas, A.; Mahfouz, M. Plant Genome Engineering for Targeted Improvement of Crop Traits. Front. Plant Sci. 2019, 10, 114. [CrossRef] [PubMed]

8. Barman, H.N.; Sheng, Z.; Fiaz, S.; Zhong, M.; Wu, Y.; Cai, Y.; Wei, X. Generation of a new ther-mo-sensitive genic male sterile rice line by targeted mutagenesis of TMS5 gene through CRISPR/Cas9 system. BMC Plant Biol. 2019, 19, 109. [CrossRef]

9. Voss-Fels, K.P.; Stahl, A.; Wittkop, B.; Lichthardt, C.; Nagler, S.; Rose, T.; Chen, T.-W.; Zetzsche, H.; Seddig, S.; Baig, M.M.; et al. Breeding improves wheat productivity under contrasting agrochemical input levels. Nat. Plants 2019, 5, 706-714. [CrossRef]

10. Chakraborty, S.; Chakraborty, N.; Agrawal, L.; Ghosh, S.; Narula, K.; Shekhar, S.; Datta, A. Next-generation protein-rich potato expressing the seed protein gene AmA1 is a result of proteome rebalancing in transgenic tuber. Proc. Nat. Acad. Sci. USA 2010, 107, 17533-17538. [CrossRef]

11. Mugode, L.; Ha, B.; Kaunda, A.; Sikombe, T.; Phiri, S.; Mutale, R.; De Moura, F.F. Carotenoid re-tention of biofortified provitamin A maize (Zea mays L.) after Zambian traditional methods of milling, cooking and storage. J. Agric. Food Chem. 2014, 62, 6317-6325. [CrossRef]

12. Ye, X.; Al-Babili, S.; Klöti, A.; Zhang, J.; Lucca, P.; Beyer, P.; Potrykus, I. Engineering the provitamin A ( $\beta$-carotene) biosynthetic pathway into (carotenoid-free) rice endosperm. Science 2000, 287, 303-305. [CrossRef]

13. Datta, A. Genetic engineering for improving quality and productivity of crops. Agric. Food Secur. 2013, 2, 1-3. [CrossRef]

14. Fiaz, S.; Wang, X.; Younas, A.; Alharthi, B.; Riaz, A.; Ali, H. Apomixis and strategies to induce apomixis to preserve hybrid vigor for multiple generations. GM Crop. Food 2020, 12, 57-70. [CrossRef] [PubMed]

15. Fiaz, S.; Ahmad, S.; Noor, M.A.; Wang, X.; Younas, A.; Riaz, A.; Riaz, A.; Ali, F. Applications of the CRISPR/Cas9 System for Rice Grain Quality Improvement: Perspectives and Opportunities. Int. J. Mol. Sci. 2019, 20, 888. [CrossRef]

16. Wang, T.; Zhang, H.; Zhu, H. CRISPR technology is revolutionizing the improvement of tomato and other fruit crops. Hortic. Res. 2019, 6, 1-13. [CrossRef] [PubMed]

17. Govindaraj, M.; Vetriventhan, M.; Srinivasan, M. Importance of Genetic Diversity Assessment in Crop Plants and Its Recent Advances: An Overview of Its Analytical Perspectives. Genet. Res. Int. 2015, 2015, 1-14. [CrossRef] [PubMed]

18. Hartung, F.; Schiemann, J. Precise plant breeding using new genome editing techniques: Opportunities, safety and regulation in the EU. Plant J. 2014, 78, 742-752. [CrossRef]

19. Čermák, T.; Baltes, N.J.; Čegan, R.; Zhang, Y.; Voytas, D.F. High-frequency, precise modification of the tomato genome. Genome Biol. 2015, 16, 1-15. [CrossRef] [PubMed]

20. Voytas, D.F.; Gao, C. Precision Genome Engineering and Agriculture: Opportunities and Regulatory Challenges. PLoS Biol. 2014, 12, e1001877. [CrossRef] [PubMed]

21. Kim, H.; Kim, J.S. A guide to genome engineering with programmable nucleases. Nat. Rev. Genet. 2014, 15, 321-334. [CrossRef]

22. Ain, Q.U.; Chung, J.Y.; Kim, Y.H. Current and future delivery systems for engineered nucleases: ZFN, TALEN and RGEN. J. Control. Release 2015, 205, 120-127. [CrossRef] [PubMed]

23. Gao, F.; Shen, X.Z.; Jiang, F.; Wu, Y.; Han, C. DNA-guided genome editing using the Natronobacterium gregoryi Argonaute. Nat. Biotechnol. 2016, 34, 768-773. [CrossRef]

24. Safari, F.; Zare, K.; Negahdaripour, M.; Barekati-Mowahed, M.; Ghasemi, Y. CRISPR Cpf1 proteins: Structure, function and implications for genome editing. Cell Biosci. 2019, 9, 36. [CrossRef]

25. Komor, A.C.; Kim, Y.B.; Packer, M.S.; Zuris, J.A.; Liu, D.R. Programmable editing of a target base in genomic DNA without double-stranded DNA cleavage. Nature 2016, 533, 420-424. [CrossRef] [PubMed]

26. Kim, Y.B.; Komor, A.C.; Levy, J.M.; Packer, M.S.; Zhao, K.T.; Liu, D.R. Increasing the genome-targeting scope and precision of base editing with engineered Cas9-cytidine deaminase fusions. Nat. Biotechnol. 2017, 35, 371-376. [CrossRef] [PubMed]

27. Zafra, M.P.; Schatoff, E.M.; Katti, A.; Foronda, M.; Breinig, M.; Schweitzer, A.Y.; Simon, A.; Han, T.; Goswami, S.; Montgomery, E.; et al. Optimized base editors enable efficient editing in cells, organoids and mice. Nat. Biotechnol. 2018, 36, 888-893. [CrossRef] [PubMed]

28. Anzalone, A.V.; Randolph, P.B.; Davis, J.R.; Sousa, A.A.; Koblan, L.W.; Levy, J.M.; Chen, P.; Wilson, C.; Newby, G.A.; Raguram, A.; et al. Search-and-replace genome editing without double-strand breaks or donor DNA. Nat. Cell Biol. 2019, 576, 149-157. [CrossRef]

29. Wolabu, T.W.; Park, J.J.; Chen, M.; Cong, L.; Ge, Y.; Jiang, Q.; Debnath, S.; Li, G.; Wen, J.; Wang, Z. Improving the genome editing efficiency of CRISPR/Cas9 in Arabidopsis and Medicago truncatula. Planta 2020, 252, 1-14. [CrossRef] 
30. Manghwar, H.; Li, B.; Ding, X.; Hussain, A.; Lindsey, K.; Zhang, X.; Jin, S. CRISPR/Cas Systems in Genome Editing: Methodologies and Tools for sgRNA Design, Off-Target Evaluation, and Strategies to Mitigate Off-Target Effects. Adv. Sci. 2020, 7, 1902312. [CrossRef]

31. Jiang, W.; Bikard, D.; Cox, D.; Zhang, F.; Marraffini, L.A. RNA-guided editing of bacterial genomes using CRISPR-Cas systems. Nat. Biotechnol. 2013, 31, 233-239. [CrossRef]

32. Cho, S.W.; Kim, S.; Kim, J.M.; Kim, J.S. Targeted genome engineering in human cells with the Cas9 RNA-guided endonuclease. Nature Biotechnol. 2013, 31, 230-232. [CrossRef]

33. Mali, P.; Yang, L.; Esvelt, K.M.; Aach, J.; Guell, M.; DiCarlo, J.E.; Norville, J.E.; Church, G.M. RNA-Guided Human Genome Engineering via Cas9. Science 2013, 339, 823-826. [CrossRef]

34. Lowder, L.G.; Zhang, D.; Baltes, N.J.; Paul, J.W.; Tang, X.; Zheng, X.; Voytas, D.F.; Hsieh, T.-F.; Zhang, Y.; Qi, Y. A CRISPR/Cas9 Toolbox for Multiplexed Plant Genome Editing and Transcriptional Regulation. Plant Physiol. 2015, 169, 971-985. [CrossRef]

35. Zetsche, B.; Gootenberg, J.; Abudayyeh, O.O.; Slaymaker, I.M.; Makarova, K.S.; Essletzbichler, P.; Volz, S.E.; Joung, J.; van der Oost, J.; Regev, A.; et al. Cpf1 Is a Single RNA-Guided Endonuclease of a Class 2 CRISPR-Cas System. Cell 2015, 163, 759-771. [CrossRef] [PubMed]

36. Moon, S.B.; Lee, J.M.; Kang, J.G.; Lee, N.E.; Ha, D.I.; Kim, S.H.; Kim, Y.S. Highly efficient genome editing by CRISPR-Cpf1 using CRISPR RNA with a uridinylate-rich 3'-overhang. Nat. Commun. 2018, 9, 1-11.

37. Liu, Y.; Han, J.; Chen, Z.; Wu, H.; Dong, H.; Nie, G. Engineering cell signaling using tunable CRISPR-Cpf1-based transcription factors. Nat. Commun. 2017, 8, 1-8. [CrossRef] [PubMed]

38. Zhang, X.; Wang, J.; Cheng, Q.; Zheng, X.; Zhao, G.; Wang, J. Multiplex gene regulation by CRISPR-ddCpf1. Cell Discov. 2017, 3, 1-9. [CrossRef] [PubMed]

39. Kim, D.; Hager, M.; Brant, E.; Budak, H. Efficient genome editing in wheat using Cas9 and Cpf1 (AsCpf1 and LbCpf1) nucleases. Funct. Integr. Genomics 2021. [CrossRef]

40. Kleinstiver, B.P.; Pattanayak, V.; Prew, M.S.; Tsai, S.Q.; Nguyen, N.T.; Zheng, Z.; Joung, J.K. High-fidelity CRISPR-Cas9 nucleases with no detectable genome-wide off-target effects. Nat. Cell Biol. 2016, 529, 490-495. [CrossRef]

41. Yin, K.; Gao, C.; Qiu, J.L. Progress and prospects in plant genome editing. Nat. Plants 2017, 3, 1-6. [CrossRef]

42. Marx, V. Base editing a CRISPR way. Nat. Chem. Biol. 2018, 15, 767-770. [CrossRef]

43. Gaudelli, N.M.; Komor, A.C.; Rees, H.A.; Packer, M.S.; Badran, A.H.; Bryson, D.I.; Liu, D.R. Programmable base editing of A• T to $\mathrm{G} \bullet \mathrm{C}$ in genomic DNA without DNA cleavage. Nature 2017, 551, 464-471. [CrossRef]

44. Khanday, I.; Skinner, D.; Yang, B.; Mercier, R.; Sundaresan, V. A male-expressed rice embryogenic trigger redirected for asexual propagation through seeds. Nat. Cell Biol. 2019, 565, 91-95. [CrossRef]

45. Eid, A.; AlShareef, S.; Mahfouz, M.M. CRISPR base editors: Genome editing without double-stranded breaks. Biochem. J. 2018, 475, 1955-1964. [CrossRef] [PubMed]

46. Rees, H.A.; Liu, D.R. Base editing: Precision chemistry on the genome and transcriptome of living cells. Nat. Rev. Genet. 2018, 19, 770-788. [CrossRef] [PubMed]

47. Fiaz, S.; Noor, M.A.; Aldosri, F.O. Achieving food security in the Kingdom of Saudi Arabia through innovation: Potential role of agricultural extension. J. Saudi Soc. Agric. Sci. 2018, 17, 365-375. [CrossRef]

48. Li, M.; Li, X.; Zhou, Z.; Wu, P.; Fang, M.; Pan, X.; Lin, Q.; Luo, W.; Wu, G.; Li, H. Reassessment of the Four Yield-related Genes Gn1a, DEP1, GS3, and IPA1 in Rice Using a CRISPR/Cas9 System. Front. Plant Sci. 2016, 7, 377. [CrossRef]

49. Xu, R.; Yang, Y.; Qin, R.; Li, H.; Qiu, C.; Li, L.; Wei, P.; Yang, J. Rapid improvement of grain weight via highly efficient CRISPR/Cas9-mediated multiplex genome editing in rice. J. Genet. Genom. 2016, 43, 529-532. [CrossRef]

50. Wang, F.; Wang, C.; Liu, P.; Lei, C.; Hao, W.; Gao, Y.; Liu, Y.G.; Zhao, K. Enhanced Rice Blast Resistance by CRISPR/Cas9-Targeted Mutagenesis of the ERF Transcription Factor Gene OsERF922. PLoS ONE 2016, 11, e0154027. [CrossRef]

51. Zhou, X.; Liao, H.; Chern, M.; Yin, J.; Chen, Y.; Wang, J.; Zhu, X.; Chen, Z.; Yuan, C.; Zhao, W.; et al. Loss of function of a rice TPR-domain RNA-binding protein confers broad-spectrum disease resistance. Proc. Natl. Acad. Sci. USA 2018, 115, 3174-3179. [CrossRef]

52. Li, Z. Health risk characterization of maximum legal exposures for persistent organic pollutant (POP) pesticides in residential soil: An analysis. J. Environ. Manag. 2018, 205, 163-173. [CrossRef]

53. Xu, R.; Li, H.; Qin, R.; Wang, L.; Li, L.; Wei, P.; Yang, J. Gene targeting using the Agrobacterium tumefaciens-mediated CRISPR-Cas system in rice. Rice 2014, 7, 5. [CrossRef]

54. Tang, L.; Mao, B.; Li, Y.; Lv, Q.; Zhang, L.; Chen, C.; He, H.; Wang, W.; Zeng, X.; Shao, Y.; et al. Knockout of OsNramp5 using the CRISPR/Cas9 system produces low Cd-accumulating indica rice without compromising yield. Sci. Rep. 2017, 7, 1-12. [CrossRef]

55. Shan, Q.; Wang, Y.; Li, J.; Gao, C. Genome editing in rice and wheat using the CRISPR/Cas system. Nat. Protoc. 2014, 9, 2395-2410. [CrossRef] [PubMed]

56. Gil-Humanes, J.; Wang, Y.; Liang, Z.; Shan, Q.; Ozuna, C.V.; León, S.S.; Baltes, N.J.; Starker, C.; Barro, F.; Gao, C.; et al. Highefficiency gene targeting in hexaploid wheat using DNA replicons and CRISPR/Cas9. Plant J. 2017, 89, 1251-1262. [CrossRef] [PubMed]

57. Kim, D.; Alptekin, B.; Budak, H. CRISPR/Cas9 genome editing in wheat. Funct. Integr. Genom. 2017, 18, 31-41. [CrossRef] [PubMed] 
58. Liang, Z.; Chen, K.; Zhang, Y.; Liu, J.; Yin, K.; Qiu, J.-L.; Gao, C. Genome editing of bread wheat using biolistic delivery of CRISPR/Cas9 in vitro transcripts or ribonucleoproteins. Nat. Protoc. 2018, 13, 413-430. [CrossRef] [PubMed]

59. Liang, Z.; Zhang, K.; Chen, K.; Gao, C. Targeted Mutagenesis in Zea mays Using TALENs and the CRISPR/Cas System. J. Genet. Genom. 2014, 41, 63-68. [CrossRef] [PubMed]

60. Shi, J.; Gao, H.; Wang, H.; Lafitte, H.R.; Archibald, R.L.; Yang, M.; Hakimi, S.M.; Mo, H.; Habben, J.E. ARGOS 8 variants generated by CRISPR-Cas9 improve maize grain yield under field drought stress conditions. Plant Biotechnol. J. 2017, 15, 207-216. [CrossRef]

61. Endo, A.; Masafumi, M.; Kaya, H.; Toki, S. Efficient targeted mutagenesis of rice and tobacco genomes using Cpf1 from Francisella novicida. Sci. Rep. 2016, 6, 38169. [CrossRef]

62. Kim, H.; Kim, S.T.; Ryu, J.; Kang, B.C.; Kim, J.S. CRISPR/Cpf1-mediated DNA-free plant genome editing. Nat. Commun. 2017, 8, 1-7. [CrossRef]

63. Lee, K.; Zhang, Y.; Kleinstiver, B.P.; Guo, J.A.; Aryee, M.J.; Miller, J.; Joung, J.K. Activities and specificities of CRISPR/Cas9 and Cas12a nucleases for targeted mutagenesis in maize. Plant Biotechnol. J. 2019, 17, 362-372. [CrossRef]

64. Tang, X.; Lowder, L.G.; Zhang, T.; Malzahn, A.A.; Zheng, X.; Voytas, D.F.; Zhong, Z.; Chen, Y.; Ren, Q.; Li, Q.; et al. A CRISPR-Cpf1 system for efficient genome editing and transcriptional repression in plants. Nat. Plants 2017, 3, 1-5. [CrossRef]

65. Wang, M.; Mao, Y.; Lu, Y.; Tao, X.; Zhu, J.-K. Multiplex Gene Editing in Rice Using the CRISPR-Cpf1 System. Mol. Plant 2017, 10, 1011-1013. [CrossRef]

66. Xu, R.; Qin, R.; Li, H.; Li, J.; Yang, J.; Wei, P. Enhanced genome editing in rice using single transcript unit CRISPR-LbCpf1 systems. Plant Biotechnol. J. 2019, 17, 553. [CrossRef] [PubMed]

67. Yin, X.; Biswal, A.K.; Dionora, J.; Perdigon, K.M.; Balahadia, C.P.; Mazumdar, S.; Chater, C.; Lin, H.C.; Coe, R.A.; Kretzschmar, T.; et al. CRISPR-Cas9 and CRISPR-Cpf1 mediated targeting of a stomatal developmental gene EPFL9 in rice. Plant Cell Rep. 2017, 36, 745-757. [CrossRef]

68. Begemann, M.B.; Gray, B.N.; January, E.; Gordon, G.C.; He, Y.; Liu, H.; Oufattole, M. Precise insertion and guided editing of higher plant genomes using Cpf1 CRISPR nucleases. Sci. Rep. 2017, 7, 11606. [CrossRef] [PubMed]

69. Lu, Y.; Zhu, J.K. Precise Editing of a Target Base in the Rice Genome Using a Modified CRISPR/Cas9 System. Mol. Plant 2017, 10, 523-525. [CrossRef] [PubMed]

70. Ren, B.; Yan, F.; Kuang, Y.; Li, N.; Zhang, D.; Zhou, X.; Zhou, H. Improved base editor for effi-ciently inducing genetic variations in rice with CRISPR/Cas9-guided hyperactive hAID mutant. Mol. Plant 2018, 11, 623-626. [CrossRef]

71. Zhong, Z.; Zhang, Y.; You, Q.; Tang, X.; Ren, Q.; Liu, S.; Yang, L.; Wang, Y.; Liu, X.; Liu, B.; et al. Plant genome editing using FnCpf1 and LbCpf1 nucleases at redefined and altered PAM sites. Mol. Plant 2018, 11, 999-1002. [CrossRef]

72. Tian, S.; Jiang, L.; Cui, X.; Zhang, J.; Guo, S.; Li, M.; Zong, M. Engineering herbicide-resistant watermelon variety through CRISPR/Cas9-mediated base-editing. Plant. Cell Rep. 2018, 37, 1353-1356. [CrossRef]

73. Zhang, Y.; Massel, K.; Godwin, I.D.; Gao, C. Correction to: Applications and potential of genome editing in crop improvement. Genome Biol. 2019, 19, 210. [CrossRef]

74. Qin, R.; Li, J.; Li, H.; Zhang, Y.; Liu, X.; Miao, Y.; Wei, P. Developing a highly efficient and wildly adaptive CRISPR-SaCas9 toolset for plant genome editing. Plant. Biotechnol. J. 2019, 17, 706. [CrossRef]

75. Li, C.; Zong, Y.; Wang, Y.; Jin, S.; Zhang, D.; Song, Q.; Zhang, R.; Gao, C. Expanded base editing in rice and wheat using a Cas9-adenosine deaminase fusion. Genome Biol. 2018, 19, 1-9. [CrossRef] [PubMed]

76. Hua, K.; Tao, X.; Zhu, J.K. Expanding the base editing scope in rice by using Cas9 variants. Plant Biotechnol. J. 2018, 17, 499-504. [CrossRef] [PubMed]

77. Negishi, K.; Kaya, H.; Abe, K.; Hara, N.; Saika, H.; Toki, S. An adenine base editor with expanded targeting scope using SpCas9-NGv1 in rice. Plant Biotechnol. J. 2019, 17, 1476. [CrossRef] [PubMed]

78. Jin, S.; Zong, Y.; Gao, Q.; Zhu, Z.; Wang, Y.; Qin, P.; Liang, C.; Wang, D.; Qiu, J.-L.; Zhang, F.; et al. Cytosine, but not adenine, base editors induce genome-wide off-target mutations in rice. Science 2019, 364, 292-295. [CrossRef]

79. Ahmar, S.; Gill, R.A.; Jung, K.H.; Faheem, A.; Qasim, M.U.; Mubeen, M.; Zhou, W. Conventional and Molecular Techniques from Simple Breeding to Speed Breeding in Crop Plants: Recent Advances and Future Outlook. Int. J. Mol. Sci. 2020, $21,2590$. [CrossRef]

80. Mishra, R.; Joshi, R.K.; Zhao, K. Base editing in crops: Current advances, limitations and future implications. Plant Biotechnol. J. 2020, 18, 20-31. [CrossRef]

81. Wang, X.; Ding, C.; Yu, W.; Wang, Y.; He, S.; Yang, B.; Liang, J. Cas12a Base Editors Induce Efficient and Specific Editing with Low DNA Damage Response. Cell Rep. 2020, 31, 107723. [CrossRef]

82. Lin, Q.; Zong, Y.; Xue, C.; Wang, S.; Jin, S.; Zhu, Z.; Wang, Y.; Anzalone, A.V.; Raguram, A.; Doman, J.L.; et al. Prime genome editing in rice and wheat. Nat. Biotechnol. 2020, 38, 582-585. [CrossRef]

83. Xu, R.; Li, J.; Lu, X.; Shan, T.; Qin, R.; Wei, P. Development of Plant Prime-Editing Systems for Precise Genome Editing. Plant Commun. 2020, 3, 100043. [CrossRef]

84. Sheng, Z.; Fiaz, S.; Li, Q.; Chen, W.; Wei, X.; Xie, L.; Jiao, G.; Shao, G.; Tang, S.; Wang, J.; et al. Molecular breeding of fragrant early-season hybrid rice using the BADH2 gene. Pak. J. Bot. 2019, 51, 2089-2095. [CrossRef]

85. Wright, H. Commercial Hybrid Seed Production. In Hybridization of Crop Plants; American Society of Agronomy Inc.: Madison, WI, USA, 2015; pp. 161-176. 
86. Ali, U.; Zhong, M.; Shar, T.; Fiaz, S.; Xie, L.; Jiao, G.; Ahmad, S.; Sheng, Z.; Tang, S.; Wei, X.; et al. The influence of Ph on Cadmium Accumulation in seedlings of Rice (Oryza sativa L.). J. Plant Gro. Reg. 2020, 39, 930-940. [CrossRef]

87. Horner, H.T.; Palmer, R.G. Mechanisms of Genic Male Sterility. Crop. Sci. 1995, 35, 1527-1535. [CrossRef]

88. Havey, M.J. The use of cytoplasmic male sterility for hybrid seed production. In Molecular Biology and Biotechnology of Plant Organelles; Springer: Berlin, Germany, 2004; pp. 623-634.

89. Ma, G.H.; Yuan, L.P. Hybrid rice achievements, development and prospect in China. J. Integr. Agric. 2015, 14, 197-205. [CrossRef]

90. Cheng, S.H.; Zhuang, J.Y.; Fan, Y.Y.; Du, J.H.; Cao, L.Y. Progress in Research and Development on Hybrid Rice: A Superdomesticate in China. Ann. Bot. 2007, 100, 959-966. [CrossRef]

91. Williams, M.; Leemans, J. Maintenance of Male-Sterile Plants. Google Patents US5750867A, 12 May 1998.

92. Zhang, Q.; Shen, B.Z.; Dai, X.K.; Mei, M.H.; Maroof, M.S.; Li, Z.B. Using bulked extremes and recessive class to map genes for photoperiod-sensitive genic male sterility in rice. Proc. Natl. Acad. Sci. USA 1994, 91, 8675-8679. [CrossRef]

93. Ding, J.; Lu, Q.; Ouyang, Y.; Mao, H.; Zhang, P.; Yao, J.; Xu, C.; Li, X.; Xiao, J.; Zhang, Q. A long noncoding RNA regulates photoperiod-sensitive male sterility, an essential component of hybrid rice. Proc. Natl. Acad. Sci. USA 2012, 109, $2654-2659$. [CrossRef]

94. Chen, R.; Zhao, X.; Shao, Z.; Wei, Z.; Wang, Y.; Zhu, L.; Zhao, J.; Sun, M.; He, R.; He, G. Rice UDP-Glucose Pyrophosphorylase1 Is Essential for Pollen Callose Deposition and Its Cosuppression Results in a New Type of Thermosensitive Genic Male Sterility. Plant Cell 2007, 19, 847-861. [CrossRef]

95. Zhang, H.L.; Chen, X.Y.; Huang, J.Z.; Zhi, E.G.; Gong, J.Y.; Shu, Q.Y. Identification and transition analysis of photo-/thermosensitive genic male sterile genes in two-line hybrid rice in China. Sci. Agric. Sin. 2015, 48, 1-9.

96. Zhou, H.; He, M.; Li, J.; Chen, L.; Huang, Z.; Zheng, S.; Zhu, L.; Ni, E.; Jiang, D.; Zhao, B.; et al. Development of commercial thermo-sensitive genic male sterile rice accelerates hybrid rice breeding using the CRISPR/Cas9-mediated TMS5 editing system. Sci. Rep. 2016, 6, 37395. [CrossRef]

97. Li, H.; Pinot, F.; Sauveplane, V.; Werck-Reichhart, D.; Diehl, P.; Schreiber, L.; Gao, Y. Cytochrome P450 family member CYP704B2 catalyzes the $\omega$-hydroxylation of fatty acids and is required for anther cutin biosynthesis and pollen exine formation in rice. Plant Cell 2010, 22, 173-190. [CrossRef]

98. Chang, Z.; Chen, Z.; Wang, N.; Xie, G.; Lu, J.; Yan, W.; Zhou, J.; Tang, X.; Deng, X.W. Construction of a male sterility system for hybrid rice breeding and seed production using a nuclear male sterility gene. Proc. Natl. Acad. Sci. USA 2016, 113, 14145-14150. [CrossRef] [PubMed]

99. Marimuthu, M.P.A.; Jolivet, S.; Ravi, M.; Pereira, L.; Davda, J.N.; Cromer, L.; Wang, L.; Nogué, F.; Chan, S.W.L.; Siddiqi, I.; et al. Synthetic Clonal Reproduction Through Seeds. Science 2011, 331, 876. [CrossRef] [PubMed]

100. D'Erfurth, I.; Jolivet, S.; Froger, N.; Catrice, O.; Novatchkova, M.; Mercier, R. Turning Meiosis into Mitosis. PLoS Biol. 2009 , 7, e1000124. [CrossRef] [PubMed]

101. Mieulet, D.; Jolivet, S.; Rivard, M.; Cromer, L.; Vernet, A.; Mayonove, P.; Pereira, L.; Droc, G.; Courtois, B.; Guiderdoni, E.; et al. Turning rice meiosis into mitosis. Cell Res. 2016, 26, 1242-1254. [CrossRef] [PubMed]

102. Wang, K. Fixation of hybrid vigor in rice: Synthetic apomixis generated by genome editing. aBIOTECH 2019, 1, 15-20. [CrossRef]

103. Kelliher, T.; Starr, D.; Richbourg, L.; Chintamanani, S.; Delzer, B.; Nuccio, M.L.; Green, J.; Chen, Z.; McCuiston, J.; Wang, W.; et al. MATRILINEAL, a sperm-specific phospholipase, triggers maize haploid induction. Nat. Cell Biol. 2017, 542, 105-109. [CrossRef]

104. Li, X.; Meng, D.; Chen, S.; Luo, H.; Zhang, Q.; Jin, W.; Yan, J. Single nucleus sequencing reveals spermatid chromosome fragmentation as a possible cause of maize haploid induction. Nat. Commun. 2017, 8, 991. [CrossRef]

105. Ferreira, L.G.; Dusi, D.M.D.A.; Irsigler, A.; Gomes, A.C.M.M.; Mendes, M.A.; Colombo, L.; Carneiro, V.T.D.C. GID1 expression is associated with ovule development of sexual and apomictic plants. Plant Cell Rep. 2017, 37, 293-306. [CrossRef]

106. Shar, T.; Sheng, Z.; Ali, U.; Fiaz, S.; Wei, X.; Xie, L.; Jiao, G.; Ali, F.; Shao, G.; Hu, S.; et al. Mapping quantitative trait loci associated with paste viscosity attributes in double haploid population of rice (Oryza sativa L.). J. Integra. Agri. 2019, 18, 2-14.

107. Ma, X.; Zhang, Q.; Zhu, Q.; Liu, W.; Chen, Y.; Qiu, R.; Wang, B.; Yang, Z.; Li, H.; Lin, Y.; et al. A Robust CRISPR/Cas9 System for Convenient, High-Efficiency Multiplex Genome Editing in Monocot and Dicot Plants. Mol. Plant 2015, 8, 1274-1284. [CrossRef]

108. Zhang, J.; Zhang, H.; Botella, J.R.; Zhu, J.-K. Generation of new glutinous rice by CRISPR/Cas9-targeted mutagenesis of the Waxy gene in elite rice varieties. J. Integr. Plant Biol. 2018, 60, 369-375. [CrossRef] [PubMed]

109. Li, J.; Sun, Y.; Du, J.; Zhao, Y.; Xia, L. Generation of Targeted Point Mutations in Rice by a Modified CRISPR/Cas9 System. Mol. Plant 2017, 10, 526-529. [CrossRef] [PubMed]

110. Shao, G.; Xie, L.; Jiao, G.; Wei, X.; Sheng, Z.; Tang, S.; Hu, P. CRISPR/CAS9-mediated editing of the fragrant gene Badh2 in rice. Chin. J. Rice Sci. 2017, 31, 216-222.

111. Sánchez-León, S.; Gil-Humanes, J.; Ozuna, C.V.; Giménez, M.J.; Sousa, C.; Voytas, D.F.; Barro, F. Low-gluten, nontransgenic wheat engineered with CRISPR/Cas9. Plant Biotechnol. J. 2018, 16, 902-910. [CrossRef] [PubMed]

112. Zhang, Y.; Li, D.; Zhang, D.; Zhao, X.; Cao, X.; Dong, L.; Liu, J.; Chen, K.; Zhang, H.; Gao, C.; et al. Analysis of the functions of TaGW2 homoeologs in wheat grain weight and protein content traits. Plant J. 2018, 94, 857-866. [CrossRef] [PubMed]

113. Qiao, Z.; Qi, W.; Wang, Q.; Feng, Y.; Yang, Q.; Zhang, N.; Wang, S.; Tang, Y.; Song, R. ZmMADS47 regulates zein gene transcription through interaction with opaque2. PLoS Genet. 2016, 12, e1005991.

114. Waltz, E. Gene-edited CRISPR mushroom escapes US regulation. Nature 2016, 532, 293. [CrossRef] [PubMed] 
115. Zhang, X.; Wang, J.; Huang, J.; Lan, H.; Wang, C.; Yin, C.; Wu, Y.; Tang, H.; Qian, Q.; Li, J.; et al. Rare allele of OsPPKL1 associated with grain length causes extra-large grain and a significant yield increase in rice. Proc. Nat. Acad. Sci. USA 2012, 109, 21534-21539. [CrossRef]

116. Li, J.; Meng, X.; Zong, Y.; Chen, K.; Zhang, H.; Liu, J.; Li, J.; Gao, C. Gene replacements and insertions in rice by intron targeting using CRISPR-Cas9. Nat. Plants 2016, 2, 16139. [CrossRef]

117. Sun, Y.; Jiao, G.; Liu, Z.; Zhang, X.; Li, J.; Guo, X.; Du, W.; Du, J.; Francis, F.; Zhao, Y.; et al. Generation of high-amylose rice through CRISPR/Cas9-mediated targeted mutagenesis of starch branching enzymes. Front. Plant Sci. 2017, 8, 298. [CrossRef]

118. Chao, S.; Cai, Y.; Feng, B.; Jiao, G.; Sheng, Z.; Luo, J.; Tang, S.; Wang, J.; Hu, P.; Wei, X. Editing of rice Isoamylase Gene ISA1 provides insights into its function in starch formation. Rice Sci. 2019, 26, 77-87.

119. Jiang, M.; Liu, Y.; Liu, Y.; Tan, Y.; Huang, J.; Shu, Q. Mutation of inositol 1, 3, 4-trisphosphate 5/6-kinase6 impairs plant growth and phytic acid synthesis in rice. Plants 2019, 8, 114. [CrossRef] [PubMed]

120. Li, X.; Zhou, W.; Ren, Y.; Tian, X.; Lv, T.; Wang, Z.; Fang, J.; Chu, C.; Yang, J.; Bu, Q. High-efficiency breeding of early-maturing rice cultivars via CRISPR/Cas9-mediated genome editing. J. Genet. Genom. 2017, 44, 175-178. [CrossRef]

121. Miao, C.; Xiao, L.; Hua, K.; Zou, C.; Zhao, Y.; Bressan, R.A.; Zhu, J.K. Mutations in a subfamily of abscisic acid receptor genes promote rice growth and productivity. Proc. Nat. Acad. Sci. USA 2018, 115, 6058-6063. [CrossRef] [PubMed]

122. Xie, K.; Yang, Y. RNA-Guided Genome Editing in Plants Using a CRISPR-Cas System. Mol. Plant 2013, 6, 1975-1983. [CrossRef]

123. Macovei, A.; Sevilla, N.R.; Cantos, C.; Jonson, G.B.; Slamet-Loedin, I.; Čermák, T.; Voytas, D.F.; Choi, I.R.; Chadha-Mohanty, P. Novel alleles of rice eIF4G generated by CRISPR/Cas9-targeted mutagenesis confer resistance to Rice tungro spherical virus. Plant Biotechnol. J. 2018, 16, 1918-1927. [CrossRef]

124. Sun, Y.; Zhang, X.; Wu, C.; He, Y.; Ma, Y.; Hou, H.; Guo, X.; Du, W.; Zhao, Y.; Xia, L. Engineering herbicide-resistant rice plants through CRISPR/Cas9-mediated homologous recombination of acetolactate synthase. Mol. Plant 2016, 9, 628-631. [CrossRef]

125. Zhang, A.; Liu, Y.; Wang, F.; Li, T.; Chen, Z.; Kong, D.; Bi, J.; Zhang, F.; Luo, X.; Wang, J.; et al. Enhanced rice salinity tolerance via CRISPR/Cas9-targeted mutagenesis of the OsRR22 gene. Mol. Breed. 2019, 39, 47. [CrossRef]

126. Mao, X.; Zheng, Y.; Xiao, K.; Wei, Y.; Zhu, Y.; Cai, Q.; Chen, L.; Xie, H.; Zhang, J. OsPRX2 contributes to stomatal closure and improves potassium deficiency tolerance in rice. Biochem. Biophys. Res. Commun. 2018, 495, 461-467. [CrossRef]

127. Nieves-Cordones, M.; Mohamed, S.; Tanoi, K.; Kobayashi, N.I.; Takagi, K.; Vernet, A.; Guiderdoni, E.; Périn, C.; Sentenac, H.; Véry, A.-A. Production of low-Cs + rice plants by inactivation of the K + transporter OsHAK1 with the CRISPR -Cas system. Plant J. 2017, 92, 43-56. [CrossRef]

128. Malzahn, A.; Lowder, L.; Qi, Y. Plant genome editing with TALEN and CRISPR. Cell Biosci. 2017, 7, 21. [CrossRef] [PubMed]

129. Zeng, D.; Li, X.; Huang, J.; Li, Y.; Cai, S.; Yu, W.; Li, Y.; Huang, Y.; Xie, X.; Gong, Q.; et al. Engineered Cas9 variant tools expand targeting scope of genome and base editing in rice. Plant Biotechnol. J. 2020, 18, 1348-1350. [CrossRef] [PubMed]

130. Hua, K.; Tao, X.; Liang, W.; Zhang, Z.; Gou, R.; Zhu, J.K. Simplified adenine base editors improve adenine base editing efficiency in rice. Plant Biotech. J. 2020, 18, 770-778. [CrossRef] [PubMed]

131. Li, J.; Qin, R.; Zhang, Y.; Xu, S.; Liu, X.; Yang, J.; Zhang, X.; Wei, P. Optimizing plant adenine base editor systems by modifying the transgene selection system. Plant Biotechnol. J. 2020, 18, 1495-1497. [CrossRef]

132. Zhang, Y.; Liang, Z.; Zong, Y.; Wang, Y.; Liu, J.; Chen, K.; Qiu, J.L.; Gao, C. Efficient and transgene-free genome editing in wheat through transient expression of CRISPR/Cas9 DNA or RNA. Nat. Commun. 2016, 7, 12617. [CrossRef] [PubMed]

133. Shan, Q.; Wang, Y.; Li, J.; Zhang, Y.; Chen, K.; Liang, Z.; Zhang, K.; Liu, J.; Xi, J.J.; Qiu, J.L.; et al. Targeted genome modification of crop plants using a CRISPR-Cas system. Nat. Biotechnol. 2013, 31, 686688. [CrossRef]

134. Wang, Y.; Cheng, X.; Shan, Q.; Zhang, Y.; Liu, J.; Gao, C.; Qiu, J.L. Simultaneous editing of three homoeoalleles in hexaploid bread wheat confers heritable resistance to powdery mildew. Nat. Biotechnol. 2014, 32, 947-951. [CrossRef]

135. Zhang, Y.; Bai, Y.; Wu, G.; Zou, S.; Chen, Y.; Gao, C.; Tang, D. Simultaneous modification of three homoeologs ofTaEDR1by genome editing enhances powdery mildew resistance in wheat. Plant J. 2017, 91, 714-724. [CrossRef]

136. Connorton, J.M.; Jones, E.R.; Rodríguez-Ramiro, I.; Fairweather-Tait, S.; Uauy, C.; Balk, J. Wheat vacuolar iron transporter TaVIT2 transports Fe and $\mathrm{Mn}$ and is effective for biofortification. Plant Physiol. 2017, 174, 2434-2444. [CrossRef]

137. Zong, Y.; Wang, Y.; Li, C.; Zhang, R.; Chen, K.; Ran, Y.; Qiu, J.L.; Wang, D.; Gao, C. Precise base editing in rice, wheat and maize with a Cas9-cytidine deaminase fusion. Nat. Biotechnol. 2017, 35, 438-440. [CrossRef]

138. Zhang, R.; Liu, J.; Chai, Z.; Chen, S.; Bai, Y.; Zong, Y.; Chen, K.; Li, J.; Jiang, L.; Gao, C. Generation of herbicide tolerance traits and a new selectable marker in wheat using base editing. Nat. Plants 2019, 5, 480-485. [CrossRef] [PubMed]

139. Svitashev, S.; Young, J.K.; Schwartz, C.; Gao, H.; Falco, S.C.; Cigan, A.M. Targeted mutagenesis, precise gene editing, and site-specific gene insertion in maize using Cas9 and guide RNA. Plant Physiol. 2015, 169, 931-945. [CrossRef] [PubMed]

140. Zhu, J.; Song, N.; Sun, S.; Yang, W.; Zhao, H.; Song, W.; Lai, J. Efficiency and inheritance of targeted mutagenesis in maize using CRISPR-Cas9. J. Genet. Genom. 2016, 43, 25-36. [CrossRef] [PubMed]

141. Li, H.; Qing, R.; Liu, X.; Liao, S.; Xu, R.; Yang, J.; Wei, P. CRISPR/Cas9-Mediated Adenine Base Editing in Rice Genome. Rice Sci. 2019, 26, 125-128. [CrossRef]

142. Delgado, C.; Mora-Poblete, F.; Ahmar, S.; Chen, J.T.; Figueroa, C.R. Jasmonates and Plant Salt Stress: Molecular Players, Physiological Effects, and Improving Tolerance by Using Genome-Associated Tools. Int. J. Mol. Sci. 2021, 22, 3082. [CrossRef]

143. Cong, L.; Ran, F.A.; Cox, D.; Lin, S.; Barretto, R.; Habib, N.; Marraffini, L.A. Multiplex genome engineering using CRISPR/Cas systems. Science 2013, 339, 819-823. [CrossRef] [PubMed] 
144. Akama-Garren, E.H.; Joshi, N.S.; Tammela, T.; Chang, G.P.; Wagner, B.L.; Lee, D.Y.; Rideout, W.M., 3rd; Papagiannakopoulos, T.; Xue, W.; Jacks, T. A Modular Assembly Platform for Rapid Generation of DNA Constructs. Sci. Rep. 2016, 18, 16836. [CrossRef]

145. Xie, K.; Minkenberg, B.; Yang, Y. Boosting CRISPR/Cas9 multiplex editing capability with the endogenous tRNA-processing system. Proc. Natl Acad. Sci. USA. 2015, 112, 3570-3575. [CrossRef]

146. Fonfara, I.; Richter, H.; BratoviÄ, M.; Le Rhun, A.; Charpentier, E. The CRISPR-associated DNA-cleaving enzyme Cpf1 also processes precursor CRISPR RNA. Nature 2016, 532, 517-521. [CrossRef]

147. Li, X.; Wang, Y.; Chen, S.; Tian, H.; Fu, D.; Zhu, B.; Luo, Y.; Zhu, H. Lycopene Is Enriched in Tomato Fruit by CRISPR/Cas9Mediated Multiplex Genome Editing. Front. Plant Sci. 2018, 9, 559. [CrossRef]

148. Feng, Z.; Zhang, B.; Ding, W.; Liu, X.; Yang, D.L.; Wei, P.; Cao, F.; Zhu, S.; Zhang, F.; Mao, Y.; et al. Efficient genome editing in plants using a CRISPR/Cas system. Cell Res. 2013, 23, 1229-1232. [CrossRef]

149. Fiaz, S.; Lv, S.; Barman, H.N.; Sahr, T.; Jiao, G.; Wei, X.; Sheng, Z.; Tang, S.; Hu, P. Analysis of Genomic regions governing cooking and eating quality traits using a Recombinant Inbred population in Rice (Oryza sativa L.). Int. J. Agri. Bio. 2019, 22, 611-619.

150. El-Mounadi, K.; Morales-Floriano, M.L.; Garcia-Ruiz, H. Principles, Applications, and Biosafety of Plant Genome Editing Using CRISPR-Cas9. Front. Plant Sci. 2020, 11, 56. [CrossRef]

151. Eckerstorfer, M.F.; Engelhard, M.; Heissenberger, A.; Simon, S.; Teichmann, H. Plants Developed by New Genetic Modification Techniques: Comparison of Existing Regulatory Frameworks in the EU and Non-EU Countries. Front. Bioeng. Biotechnol. $2019,7,26$. [CrossRef]

152. Van, V.T.; Sung, Y.W.; Kim, J.; Doan, D.T.H.; Tran, M.T.; Kim, J.-Y. Challenges and Perspectives in Homology-Directed Gene Targeting in Monocot Plants. Rice 2019, 12, 95. [CrossRef]

153. Gleim, S.; Lubieniechi, S.; Smyth, S.J. CRISPR-Cas9 Application in Canadian Public and Private Plant Breeding. CRISPR J. 2020, 3 , 44-51. [CrossRef]

154. Spicer, A.; Molnar, A. Gene Editing of Microalgae: Scientific Progress and Regulatory Challenges in Europe. Biology $2018,7,21$. [CrossRef]

155. Gao, W.; Xu, W.T.; Huang, K.L.; Guo, M.Z.; Luo, Y.B. Risk analysis for genome editing-derived food safety in China. Food Control. 2018, 84, 128-137. [CrossRef]

156. Chimata, M.K.; Bharti, G. Regulation of genome edited technologies in India. Transgenic Res. 2019, 28, 175-181. [CrossRef]

157. Zannoni, L. Evolving Regulatory Landscape for Genome-Edited Plants. CRISPR J. 2019, 2, 3-8. [CrossRef]

158. Malzahn, A.A.; Tang, X.; Lee, K.; Ren, Q.; Sretenovic, S.; Zhang, Y.; Chen, H.; Kang, M.; Bao, Y.; Zheng, X.; et al. Application of CRISPR-Cas12a temperature sensitivity for improved genome editing in rice, maize, and Arabidopsis. BMC Biol. 2019, 17, 1-14. [CrossRef] [PubMed]

159. Wolter, F.; Puchta, H. Knocking out consumer concerns and regulator's rules: Efficient use of CRISPR/Cas ribonucleoprotein complexes for genome editing in cereals. Genome Biol. 2017, 18, 43. [CrossRef]

160. Wang, P.; Zhao, F.J.; Kopittke, P.M. Engineering crops without genome integration using nanotechnology. Trends Plant Sci. 2019, 24, 574-577. [CrossRef] [PubMed]

161. Miller, J.B.; Zhang, S.; Kos, P.; Xiong, H.; Zhou, K.; Perelman, S.S.; Zhu, H.; Siegwart, D.J. Non-viral CRISPR/Cas gene editing in vitro and in vivo enabled by synthetic nanoparticle codelivery of Cas9 mRNA and sgRNA. Angew. Chem. Int. Ed. 2017, 56, 1059-1063. [CrossRef] [PubMed]

162. Ma, X.; Zhang, X.; Liu, H.; Li, Z. Highly efficient DNA-free plant genome editing using virally delivered CRISPR-Cas9. Nat. Plants 2020, 6, 773-779. [CrossRef] [PubMed]

163. Cody, W.B.; Scholthof, H.B. Native processing of single guide RNA transcripts to create catalytic Cas9/Single guide RNA complexes in planta. Plant Physiol. 2020, 184, 1194-1206. [CrossRef]

164. Metje-Sprink, J.; Menz, J.; Modrzejewski, D.; Sprink, T. DNA-free genome editing: Past, present and future. Front. Plant Sci. 2019, 9, 1957. [CrossRef]

165. Andersson, M.; Turesson, H.; Olsson, N.; Fält, A.S.; Ohlsson, P.; Gonzalez, M.N.; Samuelsson, M.; Hofvander, P. Genome editing in potato via CRISPR-Cas9 ribonucleoprotein delivery. Physiol Plant. 2018, 164, 378-384. [CrossRef]

166. Hu, J.; Li, S.; Li, Z.; Li, H.; Song, W.; Zhao, H.; Lai, J.; Xia, L.; Li, D.; Zhang, Y. A barley stripe mosaic virus-based guide RNA delivery system for targeted mutagenesis in wheat and maize. Mol. Plant Pathol. 2019, 20, 1463-1474. [CrossRef]

167. Sant'Ana, R.R.A.; Caprestano, C.A.; Nodari, R.O.; Agapito-Tenfen, S.Z. PEG-delivered CRISPR-Cas9 ribonucleoproteins system for gene-editing screening of maize protoplasts. Genes 2020, 11, 1029. [CrossRef]

168. Murovec, J.; Guček, K.; Bohanec, B.; Avbelj, M.; Jerala, R. DNA-free genome editing of Brassica oleracea and B. rapa protoplasts using CRISPR-Cas9 ribonucleoprotein complexes. Front. Plant Sci. 2018, 9, 1594. [CrossRef] [PubMed]

169. Toda, E.; Koiso, N.; Takebayashi, A.; Ichikawa, M.; Kiba, T.; Osakabe, K.; Osakabe, Y.; Sakakibara, H.; Kato, N.; Okamoto, T. An efficient DNA- and selectable-marker-free genome-editing system using zygotes in rice. Nat. Plants 2019, 5, 363-368. [CrossRef] [PubMed]

170. Wu, S.; Zhu, H.; Liu, J.; Yang, Q.; Shao, X.; Bi, F.; Hu, C.; Huo, H.; Chen, K.; Yi, G. Establishment of a PEG-mediated protoplast transformation system based on DNA and CRISPR/Cas9 ribonucleoprotein complexes for banana. BMC Plant Biol. 2020, $20,425$. [CrossRef] [PubMed]

171. Park, J.; Choi, S.; Park, S.; Yoon, J.; Park, A.Y.; Choe, S. DNA-free genome editing via ribonucleoprotein (RNP) delivery of CRISPR/Cas in lettuce. Methods Mol. Biol. 2019, 1917, 337-354. 
172. Kim, H.; Choi, J.; Won, K.-H. A stable DNA-free screening system for CRISPR/RNPs-mediated gene editing in hot and sweet cultivars of Capsicum annuum. BMC Plant Biol. 2020, 20,1-12. [CrossRef]

173. Veillet, F.; Perrot, L.; Chauvin, L.; Kermarrec, M.P.; Guyon-Debast, A.; Chauvin, J.E.; Nogué, F.; Mazier, M. Transgene-free genome editing in tomato and potato plants using Agro-bacterium-mediated delivery of a CRISPR/Cas9 cytidine base editor. Int. J. Mol. Sci. 2019, 20, 402. [CrossRef]

174. Zhang, X.H.; Tee, L.Y.; Wang, X.G.; Huang, Q.S.; Yang, S.H. Off-target effects in CRISPR/Cas9-mediated genome engineering. Mol. Ther. Nucleic Acids 2015, 4, e264. [CrossRef]

175. Pattanayak, V.; Lin, S.; Guilinger, J.P.; Ma, E.; Doudna, J.A.; Liu, D.R. High-throughput profiling of off-target DNA cleavage reveals RNA-programmed Cas9 nuclease specificity. Nat. Biotechnol. 2013, 31, 839-843. [CrossRef]

176. Li, H.; Rasheed, A.; Hickey, L.; He, Z. Fast-Forwarding Genetic Gain. Trends Plant Sci. 2018, 23, 184-186. [CrossRef]

177. Watson, A.; Ghosh, S.; Williams, M.J.; Cuddy, W.S.; Simmonds, J.; Rey, M.D.; Hatta, M.A.M.; Hinchliffe, A.; Steed, A.; Reynolds, D.; et al. Speed breeding is a powerful tool to accelerate crop research and breeding. Nat. Plants 2018, 4, 23-29. [CrossRef]

178. Yu, S.; Ali, J.; Zhang, C.; Li, Z.; Zhang, Q. Genomic breeding of green super rice varieties and their deployment in Asia and Africa. Theor. Appl. Genet. 2020, 133, 1427-1442. [CrossRef] [PubMed]

179. Ahmar, S.; Saeed, S.; Khan, M.H.; Ullah Khan, S.; Mora-Poblete, F.; Kamran, M.; Faheem, A.; Maqsood, A.; Rauf, M.; Saleem, S.; et al. A Revolution toward Gene-Editing Technology and Its Application to Crop Improvement. Int. J. Mol. Sci. 2020, 21, 5665. [CrossRef] [PubMed]

180. Ahmar, S.; Mahmood, T.; Fiaz, S.; Mora-Poblete, F.; Shafiq, M.S.; Chattha, M.S.; Jung, K.H. Genome editing with nanomaterials: A cutting edge strategy for crop improvement. Front. Plant Sci. 2021, 12, 943. 